Chapman University

Chapman University Digital Commons

$10-26-2020$

Affiliation Bias in the Online Market for Rental Accommodation

Barbara A. Bliss

Joseph Engelberg

Mitch Warachka

Follow this and additional works at: https://digitalcommons.chapman.edu/business_articles

Part of the Real Estate Commons 


\section{Affiliation Bias in the Online Market for Rental Accommodation}

\section{Comments}

This is the accepted version of the following article:

Bliss, B. A., Engelberg, J., \& Warachka, M. (2020). Affiliation bias in the online market for rental accommodation. Real Estate Economics, 49(1), 224- 266.

which has been published in final form at https://doi.org/10.1111/1540-6229.12339. This article may be used for non-commercial purposes in accordance with Wiley Terms and Conditions for Self-Archiving.

\section{Copyright}

American Real Estate and Urban Economics Association 


\title{
Affiliation Bias in the Online Market for Rental
}

\section{Accommodation*}

\author{
Barbara A. Bliss ${ }^{\dagger}$ Joseph Engelberg; and Mitch Warachka ${ }^{\S}$
}

\author{
October 2020
}

\begin{abstract}
We find evidence of taste-based discrimination against rival affiliations in the online market for rental accommodation. Airbnb hosts in college towns increase their listing prices more than hotels on home football games against rival teams. By setting listing prices too high as a result of their affiliation bias against rival fans, hosts experience a $30 \%$ reduction in rental income. The overestimation of demand, the cost (inconvenience) of temporary relocation, and the likelihood of incurring damage cannot explain the inverse relation between listing price increases and rental incomes that is limited to games against rival teams. Instead, greater financial constraints are associated with smaller listing price increases and higher rental incomes on rival games, suggesting that taste-based discrimination is a luxury.
\end{abstract}

Keywords: Affiliation Bias, Rental Accommodation, Financial Constraints

${ }^{*}$ We thank the editor, Brent Ambrose, as well as two anonymous referees along with Dave Bjerk, William Bazley, Vicki Bogan, Robert Bowen, Michael Brennan, Tom Chang, Lauren Cohen, Pingyang Gao, Diego Garcia, Daniel Greene, Samuel Hartzmark, Yaron Levi, Tim Loughran, William Mullins, Mikael Paaso, David Reeb, Jonathan Reuter, Alison Sanchez, Joshua Spizman, Richard Thaler, Fang Yu, Gaoqing Zhang, and conference participants at the 2019 Financial Intermediation Research Society, 2019 American Finance Association, 2018 Finance Down Under Conference, 2017 Oregon Summer Finance Conference, 2017 Helsinki Finance Summit, 2017 California Corporate Finance Conference at Loyola Marymount University, and 2017 Vietnam International Conference in Finance as well as seminar participants at Chapman University, CEIBS (China), and SWUFE (China) for their helpful comments and suggestions.

${ }^{\dagger}$ University of San Diego, 5998 Alcala Park, San Diego, CA, 92110. Email: bbliss@sandiego.edu

¥UCSD Rady School of Management, Otterson Hall, La Jolla, CA, 92093. Email: jengelberg@ucsd.edu

$\S$ Corresponding Author: Chapman University, 1 University Drive, Orange, CA, 92866. Email: warachka@chapman.edu

This article has been accepted for publication and undergone full peer review but has not been through the copyediting, typesetting, pagination and proofreading process, which may lead to differences between this version and the Version of Record. Please cite this article as doi: $10.1111 / 1540-6229.12339$

This article is protected by copyright. All rights reserved. 


\section{Introduction}

Our study involves Airbnb, an online marketplace for rental accommodation that enables households to monetize their real estate assets. While aggregate Airbnb usage has been shown to increase property prices and rents (Barron, Kung, Proserpio (2020), Horn and Merante (2017), Sheppard and Udell (2018)), success as an individual Airbnb host requires setting an appropriate listing price. One might think hosts set listing prices on Airbnb to maximize rental income. However, compared to hotels that have geographically diverse operations and established protocols for setting prices, the pricing decisions of Airbnb hosts may be subject to an affiliation bias that is related to personal experience in a specific geographical area.

Our first contribution is to document an affiliation bias in the online market for rental accommodation. As this analysis benchmarks Airbnb hosts to hotels, our second contribution is highlighting the ability of professional management to mitigate affiliation bias. Our third contribution is demonstrating that financial constraints also mitigate affiliation bias. Our

fourth contribution is providing empirical support for the prediction that affiliation bias reduces income in a competitive market (Becker, 1957).

Carlsson and Eriksson (2014) as well as Ahmed and Hammarstedt (2008) find evidence of racial and gender discrimination in the rental market for accommodation, while Ahmed, Andersson, and Hammarstedt (2008) do not find evidence of discrimination based on sexual orientation. Furthermore, Ahmed, Andersson, and Hammarstedt (2010) report that discrimination is not mitigated by having prospective tenants provide additional information. Thus, learning is unlikely to reduce discrimination. Our empirical results also appear to arise from taste-based preferences that cannot be mitigated by learning.

In contrast to racial and gender discrimination, few studies examine discrimination based on affiliation. Furthermore, the relatively small literature on affiliation bias typically involves third-party intermediares (Puig and Strezhev (2017)) and conflicts on interest arising from 
economic incentives (Corwin, Larocquea, and Stegemoller (2017)). Affiliation bias in these settings differs from our study of affiliation bias that arises from personal experience in a specific geographical area, which has implications for political as well as religious affiliations.

Airbnb listings in college towns provide an ideal laboratory to identify affiliation bias for several reasons. First, college football rivalries create a mutual disdain between rival fans. Cikara, Botvinick, Fiske (2011) find that "us versus them" behavior spreads beyond competitors to fans. Therefore, an affiliation bias against rival fans may be embedded into Airbnb listing prices. Second, we can observe the same host's listing price and rental income on home games against rival teams and non-rival teams. Therefore, our empirical design enables us to hold the host fixed and vary their affiliation bias toward fans of the visiting team. Third, we can compare the price-setting behavior of Airbnb hosts to benchmark hotel prices that better reflect demand. Overall, unlike typical deviations between utility and wealth maximization due to risk aversion, we study the extent to which hosts are willing compromise their income (wealth) due to a bias against rival affiliations. While our results pertain to college affiliations, political affiliations also create a mutual disdain and are highly correlated with geography. Thus, the implications of our findings are not limited to athletic competitions.

Our data consist of 1,320 entire units on Airbnb in 26 college towns encompassing 236 games during the 2014 and 2015 football seasons. Entire units resemble hotel rooms, and provide self-contained accommodations that physically separate guests from hosts. Thus, rental transactions for these units typically do not involve any interaction or reciprocity between hosts and guests. Over $60 \%$ of the total rental income earned by Airbnb hosts during the football season occurs on six home-game weekends (Friday and Saturday nights). We create a rival indicator variable that equals one on home games against a "rival" visiting team. ${ }^{1}$ This list of rivals is obtained from the sports media (e.g., ESPN and Sports Illus-

\footnotetext{
${ }^{1}$ Our list of rivals parallels the within-conference rivals obtained from Sports Illustrated in Quintanar, Deck, Reyes, and Sarangi (2015). However, their list excludes independent teams such as Notre Dame that
} 
trated) and include well-known examples such as Florida-Florida State, Notre Dame-USC, Ohio State-Michigan, and Alabama-LSU.

In the college towns we study, the Airbnb rental market is characterized by having a relatively fixed supply of units during each football season. In particular, a high average listing price is not associated with a larger or smaller number of Airbnb units being listed for rent. Thus, fluctuations in the demand for accommodation induce fluctuations in Airbnb listing prices but not the quantity of Airbnb units supplied. Consequently, the response of hosts to variation in demand is limited to varying their respective listing price. Moreover, hosts are limited to supplying indivisible units that are either booked at the listing price, generating a rental income equal to this listing price, or are not booked and generate zero rental income. Thus, a unit's occupancy status (booked or unbooked) is a discrete binary variable that determines whether or not a host receives their listing price as rental income. Our empirical tests focus on the interaction between unit-level listing prices and rental incomes since occupancy status and rental income are both functions of price and not quantity.

After controlling for unit-level heterogeneity and the demand for accommodations, we find that Airbnb hosts set higher listing prices on games against rival teams. ${ }^{2}$ Nearly two thirds of units have higher listing prices on games against rivals, with an average increase of $22 \%$. As listing prices reflect demand, we find a positive unconditional relation between listing prices and rental incomes for individual units. More important, we find that the interaction between unit-level listing prices and the rival indicator variable exerts a negative impact on rental incomes. Consequently, listing price increases on games against rivals reduce rental incomes. This inverse relation on games against rivals is confirmed after orthogonalizing listing price increases to multiple demand proxies.

As an illustration, Florida State had home games in Tallahassee against Notre Dame and the University of Florida during the 2014 college football season. For the home game are not members of any conference.

${ }^{2}$ Unit fixed effects account for variation in the quality and average listing price of individual units. 
against the fifth ranked team, Notre Dame, Airbnb units in Tallahassee were listed for an average listing price of $\$ 201$. Each unit was booked for this game, resulting in an average rental income of $\$ 201$. However, five weeks later, on the home game against the unranked but rival University of Florida team, the average listing price in Tallahassee was increased to $\$ 267$ but an average rental income of only $\$ 67$ materialized. ${ }^{3}$ Across the full sample, the following table summarizes the unit-level relation between changes in listing prices and changes in rental incomes illustrated by the above example:

Comparison of Games Against Rivals Versus Top Ranked Non-Rivals

\begin{tabular}{|c|c|c|}
\hline Change in Listing Price & Change in Occupancy & Change in Rental Income \\
\hline Above $20 \%$ & $-36.27 \%$ & $-77.98 \%$ \\
\hline $10 \%$ to $20 \%$ & $-11.63 \%$ & $-36.53 \%$ \\
\hline$-5 \%$ to $10 \%$ & $12.19 \%$ & $9.23 \%$ \\
\hline
\end{tabular}

Consequently, compared to home games against a top 25 ranked non-rival visiting team, an Airbnb host that increases their unit's listing price by $20 \%$ or more on a home game against a rival visiting team reduces their rental income by $78 \%$.

Furthermore, across the full sample, for every dollar in rental income earned by Airbnb hosts on games against highly ranked non-rival teams, only $\$ 0.71$ is earned on games against rivals. For comparison, hotels obtain $\$ 0.96$ in revenue on games against rivals relative to games against highly ranked non-rival teams. Figure 1 illustrates the listing price differences for Airbnb units relative to hotel room prices on games against rivals. This figure also illustrates that hotel prices increase more than Airbnb listing prices on homecoming, which corresponds to a large influx of home team fans. Therefore, Airbnb hosts do not increase their listing prices more than hotels on every home game, indicating that hosts do not systematically overestimate the demand for accommodations. Placebo tests also confirm the uniqueness of games against rivals since there is no inverse relation between listing price

\footnotetext{
${ }^{3}$ Individual Airbnb hosts can experience a larger loss than the average loss on rival games since each unit's occupancy is binary and zero rental income is the consequence of setting too high a listing price.
} 
increases and rental incomes on homecoming games or home games against highly ranked non-rival teams. ${ }^{4}$

A further analysis reveals that the financial constraints of hosts influence listing prices and rental incomes. Each college town is divided into areas where residents are either financially unconstrained or financially constrained based on their utilization of available credit. We find that higher listing prices on games against rivals are concentrated in zip codes with financially unconstrained hosts. On average, financially unconstrained hosts and financially constrained hosts earn similar rental incomes; $\$ 189$ and $\$ 187$ per night, respectively, on games against highly ranked non-rival visiting teams. However, on games against rivals, the average rental income of financially unconstrained hosts declines by over $20 \%$ to $\$ 149$, while the average for financially constrained hosts is nearly unchanged at $\$ 183$. This evidence indicates that financial constraints reduce the impact of affiliation bias. Intuitively, animosity toward rival affiliations is a luxury that financially constrained hosts cannot afford to incorporate into their listing prices as additional evidence finds that competition ensures affiliation bias reduces rental income.

In contrast to entire units, shared units on Airbnb have common facilities (bathroom, kitchen, etc) and are suitable for visiting fans of the home team such as alumni. Thus, selfselection in the real estate market (Longhofer and Peters (2005)) enables Airbnb hosts to infer whether prospective guests are fans of the rival team or home team based on their choice of an entire unit or shared unit, respectively. We find that both financially unconstrained hosts and financially constrained hosts of shared units do not increase their listing prices on games against rivals. This finding is consistent with rival visiting fans avoiding shared units to avoid interacting with the local population.

We examine several alternative hypotheses for the high listing prices on games against rivals. First, we find no evidence that high listing prices are needed to compensate hosts

\footnotetext{
${ }^{4}$ Although hosts without a booking may be more likely to attend a home game, this possibility cannot explain the inverse relation between listing price increases and rental incomes that is unique to rival games.
} 
for the cost (inconvenience) of having to vacate their Airbnb unit and temporarily relocate. This compensation would apply to any booking, including those on away games. However, as low listing prices on away games do not decrease the supply of Airbnb units, high listing prices are not necessary to compensate hosts for having to temporarily relocate. ${ }^{5}$ Second, listing price variation across different weekends is difficult to reconcile with hosts having a lottery preference. Instead, a lottery preference implies hosts consistently set a high listing price and accept the low probability of their unit being booked. Third, the need to learn about demand is incompatible with a host's ability to lower their listing price anytime before the game, while conditioning on information available from Airbnb regarding the occupancy status and listing price of other units. Furthermore, both a lottery preference and learning are difficult to reconcile with the inverse unit-level relation between listing price increases and rental incomes being limited to games against rival teams. Fourth, we find no evidence that games against rivals are associated with a higher cost of providing accommodation as a result of greater damage. Airbnb hosts do not increase damage deposits on games against rivals and Airbnb provides hosts with a million dollars in property insurance. ${ }^{6}$ In addition, Airbnb hosts are not more likely to block their unit from being rented on games against rivals. Moreover, while financial constraints mitigate the impact of rival visiting teams on listing prices, blocking by hosts is not sensitive to financial constraints. Moreover, providing accommodations on home games against rival teams does not increase subsequent blocking to facilitate repairs.

Overall, the ability of financial constraints to mitigate affiliation bias against rival fans is consistent with taste-based preferences in a competitive market. However, the importance of financial constraints to the relation between listing prices and rental incomes is difficult to reconcile with alternative explanations based on higher expected damage, the overestimation of demand, or the need for greater learning.

\footnotetext{
${ }^{5}$ Intuitively, the Airbnb units in our sample are unlikely to have full time occupants.

${ }^{6}$ The website www.airbnb.com/guarantee details the insurance provided by Airbnb to its hosts.
} 
In terms of economic significance, the inability to obtain a booking on the Saturday night of a home game against a rival team results in an average rental loss of $\$ 325.06$ or $33.9 \%$ of the unit's monthly mortgage payment. Similarly, the failure to obtain a booking for both Friday and Saturday night results in a $\$ 662.37$ loss, or $68.8 \%$ of the unit's monthly mortgage payment. The magnitude of this dollar-denominated loss parallels Agarwal, BenDavid, and Yao (2017)'s finding that poor mortgage decisions cost hosts an average of $\$ 700$ per refinancing. However, in contrast to these infrequent financial decisions, the failure to obtain bookings on home games due to affiliation bias represents a recurring loss.

Our study contributes to the literature that studies the impact of competition on lending discrimination (Bartlett, Morse, Stanton, and Wallace (2019)). Although Airbnb hosts with unique rental units have limited pricing power, Airbnb hosts operate in a competitive market that has low search costs and low entry barriers. Consistent with the importance of competition, Airbnb hosts who price discriminate suffer a loss of rental income. ${ }^{7}$ Moreover, taste-based price discrimination against specific affiliations is more subtle than discrimination based on ethnicity or gender (Lu and Munneke (2017), Ge, Knittel, MacKenzie, and Zoepf (2016), Bertrand and Mullainathan (2004), King and Mieszkowski (1973)). Consequently, affiliation bias may be more difficult to eradicate, especially if affiliation (location) data becomes more available. In summary, our study motivates further research on the implications of affiliation bias in real estate since our results likely generalize to other affiliations correlated with geography such as political affiliations.

\section{Data}

Using the Airbnb platform, guests can book accommodations at the listing prices specified by hosts on specific dates. Our analysis uses Airbnb information obtained from AIRDNA

\footnotetext{
${ }^{7}$ Airbnb hosts incur a high cost (zero rental income) when affiliation bias results in their unit being vacant on a home game weekend.
} 
(www.airdna.co), which specializes in collecting and processing Airbnb data. Our sample of Airbnb units are located in college towns during the 2014 and 2015 college football seasons. In this sample, Airbnb bookings are concentrated on home football games and typically involve two nights of accommodation. The start of the sample period ensures an adequate supply of Airbnb units in each college town, while the end of the sample period predates listing price recommendations provided by Airbnb. Thus, our results are not influenced by pricing algorithms that subsequently became available to Airbnb hosts.

Variation in listing prices during the football season is dramatic for Airbnb units located in college towns since home games represent large anticipated demand increases for accommodations. We examine units whose listing price changes at least once during the football season to ensure the Airbnb hosts in our sample are active. Requiring at least one price change during the football season removes inactive hosts whose listing prices fail to account for the difference between home games versus away games. Throughout the remainder of the paper, all results pertain to units whose listing price changed at least once. This subset comprises $39.2 \%$ of all units and produces qualitatively similar results as the full sample. The average number of units per college town increases from 10 in 2014 to 45 in 2015 as Airbnb increased in popularity. Initially, we focus on entire units that resemble large hotel rooms with self-contained facilities. Entire units are appropriate for visitors who prefer being physically separate from fans of the home team, although a later empirical test examines shared units.

We examine the top 30 ranked college football programs for the 2014 and 2015 football seasons. In alphabetical order, these teams include: Arizona State University, University of Alabama, University of Arkansas, Auburn University, University of California-Los Angeles, Clemson University, University of Florida, Florida State University, University of Georgia, University of Iowa, University of Kentucky, Louisiana State University, University of Michigan, Michigan State University, Mississippi State University, University of Nebraska, University of Notre Dame, Ohio State University, University of Oklahoma, University of Oregon, 
Oregon State University, Stanford University, University of Southern California, University of South Carolina, Texas Christian University, University of Tennessee, University of Texas, Texas Tech University, University of Utah, and University of Wisconsin. This collection of teams spans the entire United States. After dividing college towns into three regions (South, Midwest, and West), unreported results indicate that our main results are similar within each region. However, later reported results indicate that greater competition among rental accommodation providers within a college town increases the financial repercussions of affiliation bias.

To identify pairs of rival teams, we require at least 50 prior games between the two teams. If a team does not have at least one home game against a rival, the team's entire season is eliminated from the sample. Our final sample consists for 236 unique home games, of which 42 games are against a rival. Appendix A contains a complete list of rivals. We identify two determinants of a college football rivalry: rival teams have played each other for many years and have a won-loss record near parity. As the first game between rivals often occurred before long-distance travel was made convenient by interstate highways and aviation, rivals are often located in the same state or contiguous states. However, our empirical results are robust to controlling for the log distance between college football stadiums and to controlling for teams in the same athletic conference. ${ }^{8}$ This robustness is consistent with many visiting fans being alumni who do not reside in the visiting team's college town after graduation.

We limit our main analysis to college towns with fewer than 1,000 entire unit listings on Airbnb per football season to exclude home games in urban areas such as Los Angeles (teams excluded: USC, UCLA, Stanford, and Texas). We also restrict our sample of Airbnb listings to units located within 15 miles of the stadium.

A unit-level Airbnb Listing Premium is calculated as the listing price on a specific game

\footnotetext{
${ }^{8}$ To clarify, there is little variation in stadium attendance across home games, although the composition of home team versus visiting team fans may vary if, for example, lower ranked visiting teams have fewer fans in attendance.
} 
minus the unit's average listing price across all home games. A later robustness test computes the Airbnb Listing Premium as a percentage deviation rather than a dollar-denominated deviation. However, prospective guests are more likely to be concerned with dollar-denominated quantities than percentages since the former are posted on Airbnb. Our study also utilizes average hotel prices, occupancy rates, and income from STR, formerly known as Smith Travel Research, within a 15 mile radius of each college football stadium. A description of the hotel data provided by STR is accessible from str.com, with specific information pertaining to academic research accessible from str.com/training/academic-resources. Corgel, Liu, and White (2015) among many other academic studies also use STR data on hotels.

A college town-level Hotel Premium is then computed as the average hotel price on a specific game minus the average hotel price across all home games, with a later robustness test also computing the Hotel Premium as a percentage deviation. The average number of hotel rooms in a college town is 7,646 and the median number of rooms is 5,121 . College towns that receive more visitors throughout the year may have a larger supply of hotel rooms, and therefore a more competitive market for rental accommodation. A later analysis examines the impact of competition on both the listing prices and rental incomes of Airbnb hosts.

\section{Empirical Results}

To illustrate our testable joint-hypothesis regarding unit-level listing price increases and rental incomes, the absence of affiliation bias implies the host sets the listing price to maximize their unit's rental income

$$
\text { Rental Income }=\text { Listing Price } \times \text { Probability }(\text { Occupancy } \mid \text { Listing Price })
$$


For simplicity, assume occupancy is determined by the following decreasing linear function

$$
\text { Probability (Occupancy } \mid \text { Listing Price) }=1-\alpha P
$$

where $\alpha>0$ defines the demand curve for accommodations. In our empirical estimation, variation in $\alpha$ across home games is captured by hotel prices, team rankings, and game characteristics. With $P$ denoting the unit's listing price, the maximization in Equation (1) is equivalent to maximizing $P \times[1-\alpha P]$, which obtains its maximum at $\frac{1}{4 \alpha}$ by setting $P=\frac{1}{2 \alpha}$. Observe that increased demand reflected in a lower $\alpha$ simultaneously increases listing prices as well as occupancy. This dual impact of demand is captured by later results in Table 3.

To incorporate affiliation bias against rival fans, let $P_{R}=P+D$ denote a host's listing price on games against rivals. $D$ differs from $\alpha$ along two dimensions. First, our empirical implementation only allows $D$ to be non-zero on games against rivals, while $\alpha$ can vary across home games due to differences in demand. Second, in contrast to $\alpha, D$ can vary across hosts. As bias against rival fans increase listing prices beyond levels justified by demand, rental income is reduced to $\frac{1}{4 \alpha}-\alpha D^{2}$ on games against rivals. ${ }^{9}$

Overall, evidence that affiliation bias confound host financial decisions requires both higher listing prices and lower rental incomes on games against rivals. This inverse relation occurs when listing price increases induce a sufficiently large reduction in occupancy.

\subsection{Summary Statistics}

Table 1 reports the average number of units listed, listing price, rental income, listing premium, and occupancy rate on different home games for entire units listed on Airbnb. For comparison, the average price, revenue, hotel premium, and occupancy rate of hotels are

\footnotetext{
${ }^{9}$ The constraint $D \leq \frac{1}{2 \alpha}$ prevents the host's occupancy, and rental income, from being negative by preventing the host from setting a listing price that is twice the amount justified by demand.
} 
also reported. The average Airbnb listing price of $\$ 277.06$ across home games is highest on games against rival visiting teams, which corresponds to the highest Airbnb listing premium of $\$ 28.77$ but a relatively low occupancy rate of $65.03 \%$. Consequently, home games against rival teams fail to generate the highest average rental income.

In contrast to Airbnb units, hotel prices on games against rivals are not at their highest. Instead, hotel price increases are largest on games against top-ranked visiting teams (both incoming rankings and pre-season rankings), whereas Airbnb hosts only marginally increase their listing prices on games against top-ranked visiting teams. The occupancy rate of Airbnb units and hotels are both highest for games against top-ranked visiting teams, suggesting that these games are associated with the highest demand for accommodations.

Table 1 also reports that the supply of entire units listed on Airbnb is stable across both home and away games. Consequently, lower rental income on games against rivals cannot be attributed to an increased supply of Airbnb units. Moreover, the supply of Airbnb units does not decrease on away games when listing prices are low. If hosts did require compensation for the cost (inconvenience) of having to temporarily relocate, this compensation would apply to all bookings. However, the stable supply of Airbnb units at low listing prices on away games indicates that high listing prices are not necessary to compensate hosts for having to temporarily relocate. Hosts can also block their unit from being rented on dates they intend to occupy the unit. Blocking reflects demand by hosts for a unit, rather than the demand by guests. While blocking lowers the supply of Airbnb units, games against rivals correspond with the least amount of blocking. Instead, blocking is highest on homecoming.

In addition, the occupancy rate of hotel rooms is consistently below 100\%, especially on games against rivals. Therefore, Airbnb listing prices are set in an environment where hotel rooms are available. ${ }^{10}$ Competition from hotel rooms limits the pricing power of Airbnb

\footnotetext{
${ }^{10}$ Unreported results examine a subset of Airbnb units that accommodate between one and four adults, which is comparable to a standard hotel room. As few Airbnb units accommodate more than four adults, our results are similar for this "matched" subset.
} 
hosts and is examined in a later analysis.

To clarify, there are minor differences between the average rental income in Table 1 versus the product of the average listing price and average occupancy rate. For example, the average rental income of $\$ 176.36$ on home games against rivals is slightly lower than the product of the averages, $\$ 277.06 \times 65.03 \%=\$ 180.17$. This minor difference is explained by slightly less expensive units being rented on home games against rivals relative to the average listing price.

\subsection{Listing Price}

We now verify the assumption underlying Equation (1) that occupancy, which determines supply, is a function of price while price is independent of supply in our setting. While ex-post sporting outcomes (Edmans, Garcia, and Norli (2007)) can affect sentiment, the listing prices we study are set by hosts before the game. Specifically, the high average listing premium on games against rivals in Table 1 motivates an analysis of listing premiums using the following panel regression

$$
\text { Airbnb Listing Premium } \text { Prt }=\beta_{1} \operatorname{Rival}_{i, t}+\gamma X_{t}+\epsilon_{i, t} \text {, }
$$

in which standard errors are clustered according to the home team. This specification includes unit fixed effects that control for the each unit's quality, including its location (distance to the stadium). Throughout our empirical tests, the constant term is not suppressed when estimating panel regressions. However, this coefficient is not reported since the constant's interpretation in the presence of unit fixed effects is unclear.

The control variables that define $X$ are proxies for demand. These proxies include an indicator variable for games during prime time, which equals one if the game occurs after $5 \mathrm{pm}$ local time, and an indicator variable for homecoming games. The rank of the home team and the rank of the visiting team before the game are also included (specifically their 
respective natural log), along with an indicator variable for whether the opponent was ranked among the top 25 college football teams before the season started. To complement distance, a Same Conference indicator variable equals one if the home team and visiting team are in the same athletic conference. Furthermore, to complement the price premium of hotels as a proxy for demand on individual games, we include the occupancy of hotels. The number of entire units listed on Airbnb accounts for the supply of Airbnb accommodation. A full list of variable definitions is contained in Appendix B.

To clarify, a unit's Airbnb Listing Premium varies across different home games. While the inclusion of unit fixed effects also converts listing prices into a similar premium, our next analysis has rental income as the dependent variable and conditions on the Airbnb Listing Premium in order to examine the unit-level relation between listing price increases and rental incomes. Nevertheless, a later robustness test replaces the price premium with unadjusted listing prices as the dependent variable in Equation (2) and finds similar results.

The $\beta_{1}$ coefficient for Rival in Equation (2) determines whether games against rivals are associated with a larger listing premium after controlling for a multitude of demand proxies. The positive $\beta_{1}$ coefficients in Panel A of Table 2 indicate that Airbnb hosts significantly increase their listing prices on games against rivals. For example, the 19.497 coefficient $(t$ statistic of 4.431) in the last specification indicates that listing prices are higher on games against rivals compared to the average home game, after accounting for demand.

The results in Panel A of Table 2 indicate that Airbnb listing prices co-move with hotel prices as both respond to fluctuations in the demand for accommodations. In particular, the coefficients for Hotel Premium are positive, while the coefficients for Hotel Occupancy are negative. Thus, competition from hotels dampens the ability of Airbnb hosts to set high listing prices. The negative coefficients for Prime Time Game are at odds with the positive coefficients in Panel B of Table 2 for hotels. Intuitively, prime time games are important, although the interpretation of this indicator variable's coefficient is complicated by its correlation with Hotel Premium, which is higher on prime time games according to 
our next analysis.

Hotel prices are unlikely to be influenced by affiliation bias due to governance mechanisms that ensure their prices are profit maximizing. With hotel prices providing a proxy for demand, we repeat the estimation of Equation (2) using Hotel Premium as the dependent variable. ${ }^{11}$ Panel B of Table 2 reports that hotel prices are consistently higher on homecoming games but not on games against rivals since the $\beta_{1}$ coefficient for Rival is only marginally significant in a subset of specifications. Thus, games against rivals are not associated with the highest demand across all home games.

In contrast to games against rivals, the positive coefficient for Homecoming signifies higher demand for accommodations. The positive coefficients for Prime Time Game, PreSeason Top 25 Opponent, and Same Conference also signify that hotels increase prices due to the greater willingness of fans to travel and attend the game. Note that the insignificant coefficients for Homecoming, Pre-Season Top 25 Opponent, and Same Conference in Panel A of Table 2 are consistent with these variables being correlated with Hotel Premium.

\subsection{Occupancy}

Equation (1) assumes that the likelihood a unit is booked decreases with its listing price. To verify this assumption, our next specification has an indicator variable equaling one if a unit is booked and zero otherwise as the dependent variable

$$
\begin{aligned}
\text { Occupancy }_{i, t}= & \beta_{1} \text { Airbnb Listing Premium } \\
i, t & +\beta_{2} \operatorname{Rival}_{i, t} \\
& +\beta_{3} \text { Airbnb Listing Premium } \\
i, t & \times \operatorname{Rival}_{i, t}+\gamma X_{t}+\epsilon_{i, t} .
\end{aligned}
$$

This specification includes the interaction between the Airbnb Listing Premium and the Rival indicator variable. While a positive $\beta_{1}$ coefficient is consistent with higher listing

\footnotetext{
${ }^{11}$ To clarify, hotel prices refer to transaction prices. An alternative demand benchmark based on hotel listing prices produces identical findings.
} 
prices reflecting greater demand for accommodations, a negative $\beta_{3}$ coefficient signifies that a high listing premium on games against a rival team lowers the likelihood a unit is booked. According to Table 3 , the negative $\beta_{3}$ coefficients indicate that listing price increases on games against rivals reduce the likelihood of a booking.

A negative $\beta_{2}$ coefficient for the Rival indicator variable would indicate that hosts discriminate against rival fans by rejecting their attempted booking. However, the non-negative $\beta_{2}$ coefficients are inconsistent with this form of discrimination. Indeed, as $95.5 \%$ of hosts activate Airbnb's Instant Book feature, guests can obtain immediate confirmation of their booking without host intervention. ${ }^{12}$

The positive coefficients for Hotel Premium and Hotel Occupancy indicate that the occupancy of Airbnb hosts increases with the demand for hotel accommodations. However, in unreported results, hotel occupancy rates do not produce a negative $\beta_{2}$ coefficient nor a negative $\beta_{3}$ coefficient.

Equation (3) conditions on the rival indicator function and the Airbnb Listing Premium, with the latter also conditioning on the rival indicator function according to Equation (2). To address this nested dependency, we orthogonalize the Airbnb Listing Premium with respect to the demand proxies in $X$ to create an Orthogonal Airbnb Listing Premium variable that captures listing price fluctuations unrelated to demand. ${ }^{13}$ Consistent with Figure 1, the average Orthogonal Airbnb Listing Premium is positive on home games against rivals and negative on home games against non-rival visiting teams. We then modify Equation (3) by estimating the following panel regression

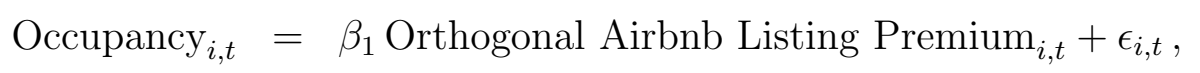

\footnotetext{
${ }^{12}$ Edelman, Luca, and Svirsky (2017) create fake guest Airbnb accounts and find that hosts are more likely to reject prospective guests who are minorities. However, their empirical design does not examine the price mechanism that is the basis of our study.

${ }^{13}$ The Orthogonal Airbnb Listing Premium variable is created using the ORTHOG command in STATA.
} 
separately for home games against rival visiting teams and non-rival visiting teams. Unit fixed effects are included in both estimations. Unreported results confirm that the $\beta_{1}$ coefficient is negative (positive) on home games against rival (non-rival) teams. Therefore, consistent with hosts having an affiliation bias against rival fans, listing price increases unrelated to demand are associated with a lower occupancy on home games against rival visiting teams.

Overall, rental income is the product of a unit's listing price and its discrete occupancy status (booked or unbooked), which is decreasing with its listing price. As our analysis of rental income pertains to single indivisible units, occupancy status and rental income are both functions of the listing price set by the unit's host and not the quantity of units supplied.

\subsection{Rental Income}

Conditional on a unit being booked, the unit's rental income equals its listing price. Without a booking, rental income equals zero. Our next analysis examines the impact of unit-level listing premiums on rental incomes using the following panel regression

$$
\begin{aligned}
& \text { Rental Income }_{i, t}= \beta_{1} \text { Airbnb Listing Premium } \\
& \\
&+\beta_{3} \text { Airbnb Listing } \text { Premium }_{i, t} \times \beta_{2} \operatorname{Rival}_{i, t} \\
& \operatorname{Rival}_{i, t}+\gamma X_{t}+\epsilon_{i, t},
\end{aligned}
$$

with unit fixed effects. A negative $\beta_{3}$ coefficient for the interaction variable (Airbnb Listing Premium $\times$ Rival) signifies that listing price increases on games against rivals are inversely related to rental income. Thus, a negative $\beta_{3}$ coefficient is evidence that listing prices are set too high on rival games. Conversely, the alternative hypothesis that listing prices are set too low on non-rival games posits a positive $\beta_{3}$ coefficient as listing price increases on rival games are required to increase rental income. 
The positive $\beta_{1}$ coefficients in Table 4 are consistent with hosts earning higher rental incomes by setting higher listing prices. This coefficient captures the positive relation between listing prices and demand. Similarly, we find a 0.526 correlation between hotel prices and hotel occupancy that arises from their joint dependence on demand. To clarify, the $\beta_{3}$ coefficient isolates the marginal impact of rival games on the rental income of hosts who increase their listing price on these specific games, while the $\beta_{1}$ coefficient captures the general impact of listing price increases on host rental income on all other games. Thus, the $\beta_{3}$ coefficient is sufficient to determine whether listing price increases on rival games are too high.

The following illustrative example clarifies the distinction between the $\beta_{1}$ and $\beta_{3}$ coefficients. Imagine an Airbnb host that typically lists her unit for $\$ 100$ per night. There are two home games in which she raises the listing price to $\$ 150$; a rival game and a matched non-rival game (for example a home game against a highly ranked non-rival visiting team). The positive coefficient for Airbnb Listing Premium and negative coefficient for the Airbnb Listing Premium $\times$ Rival interaction indicates that when she increases the listing price $\$ 50$, she is more likely to have a guest on the non-rival game relative to the rival game. This is evidence that the listing price increase on the rival game is too high relative to the matched non-rival game.

However, the insignificant $\beta_{2}$ coefficients and negative $\beta_{3}$ coefficients indicate that hosts increase listing prices on games against rivals to levels that lower their respective rental incomes. In the specification with all control variables, the $\beta_{3}$ coefficient equals $-0.272(t$ statistic of -2.101). This reduction in rental income is consistent with an affiliation bias that confounds the listing prices set by hosts. ${ }^{14}$ The inverse relation between listing price increases and rental incomes captured by the $\beta_{3}$ coefficient is unlikely to be explained by

\footnotetext{
${ }^{14}$ Although Equation (1) indicates that rental income is a quadratic function of a unit's listing price, unreported results confirm that our empirical results are robust to the inclusion of squared and cubed listing premiums that capture this non-linearity.
} 
inexperience or a lack of information regarding demand since Airbnb hosts have months to lower their listing price before the game. Furthermore, hosts can access both the occupancy status and listing price of other Airbnb units in their area.

The economic significance of our results are comparable to those of Agarwal, Ben-David, and Yao (2017). These authors find that poor mortgage decisions cost households approximately $\$ 700$ per financing. Failure to secure a guest booking on a game against a rival due to a high listing price translates into a similar dollar-denominated loss (over three nights). However, this recurring loss would typically occur each year, while a mortgage refinancing is less frequent. Furthermore, our results may underestimate the economic importance of college football rivalries in the total population since "superfans" are unlikely to rent their units on home games. ${ }^{15}$

\subsection{Additional Results}

Several additional results using alternative econometric implementations confirm the impact of rival games on the listing prices and rental incomes of Airbnb hosts. The first additional result arises from jointly estimating Equations (2) and (5) using a Seemingly Unrelated Regression (SUR) procedure to allow for correlated error terms. The results in Panel A of Table 5 confirm our earlier results as the $\beta_{1}$ coefficient is positive and the $\beta_{3}$ coefficient is negative in the analysis of listing prices and rental incomes, respectively. Therefore, the joint estimation of these coefficients does not alter our earlier conclusion that hosts increase listing prices on games against rivals to levels that reduce their rental incomes.

The second additional result replaces the dollar-denominated Airbnb Listing Premium and the dollar-denominated Hotel Premium with premiums that are expressed as percentage deviations before re-estimating Equations (2) and (5). The results in Panel B of Table 5

\footnotetext{
${ }^{15}$ Across all Airbnb hosts with entire units, $11.75 \%$ block their unit from being rented on every home game. These "superfans" may attend each home game, although their units do not have listing prices on home games to analyze.
} 
confirm that Airbnb hosts increase listing prices on games against rivals to levels that reduce their respective rental income. Therefore, we continue to find a positive $\beta_{1}$ coefficient in Equation (2) and a negative $\beta_{3}$ coefficient in Equation (5) after expressing the Airbnb Listing Premium and Hotel Premium as percentage deviations (instead of dollar-denominated deviations).

The third additional result replaces the Airbnb Listing Premium in Equation (2) with the ratio of Airbnb listing prices to hotel prices. In particular, this ratio normalizes unit-level Airbnb listing prices by the average hotel price in the same college town on the same date to capture relative pricing. Game-specific premiums are then computed each weekend based on time series variation in this ratio throughout the football season. The results in Panel $\mathrm{C}$ of Table 5 confirm that the listing prices of Airbnb units increase more on games against rivals than hotel prices, and these increases are suboptimal in terms of rental income.

The fourth additional result replaces the Airbnb Listing Premium in Equation (2) with unadjusted Airbnb listing prices since unit-fixed effects ensure the dependent variable is listing price deviations from the average listing price across all home game. However, the $\beta_{1}$ coefficient in Panel D of Table 5 equals 21.310 ( $t$-statistic of 4.854). This coefficient's magnitude parallels its counterpart in Panel A of Table 2 for the Airbnb Listing Premium. Thus, the impact of games against rivals on listing prices does not depend on whether this impact is expressed as a dollar amount or percentage.

Overall, our main results regarding listing prices and rental incomes on home games against rival teams are insensitive to alternative econometric implementations.

\subsection{Residual Airbnb Listing Premium}

To ensure our results are not driven by demand, we construct a unit-level Residual Listing Premium by regressing the original Airbnb Listing Premium on the Hotel Premium of each college town. This Residual Listing Premium is defined by the residual from this regression 
and captures listing price increases that are orthogonal to demand. Equations (2) and (5) are then re-estimated using the Residual Listing Premium.

The results in Table 6 parallel our earlier results as the $\beta_{3}$ coefficient for the interaction between the Residual Listing Premium and the Rival indicator variable is negative. Therefore, after controlling for demand using hotel prices, these results confirm that affiliation bias offers the most likely explanation for the inverse unit-level relation between listing price increases and rental incomes on games against rivals.

\subsection{Placebo Tests for Demand}

Homecoming games coincide with an influx of home team fans. As homecoming games are associated with a high demand for accommodations and a friendly atmosphere, we reestimate Equation (5) after replacing the Rival indicator variable with the indicator variable for Homecoming. Panel A of Table 7 reports insignificant $\beta_{3}$ coefficients for the interaction variable defined as Airbnb Listing Premium $\times$ Homecoming. Thus, there is no inverse unitlevel relation between listing price increases and rental incomes on homecoming games.

Games against highly ranked visiting teams that are not rivals are also associated with a high demand for accommodations. Thus, our second placebo test replaces the Rival indicator variable with an indicator variable for games against opponents that were ranked in the top 25 before the start of the college football season. Panel B of Table 7 reports insignificant $\beta_{3}$ coefficients for games against top ranked teams.

Overall, our placebo tests indicate that Airbnb hosts do not set suboptimal listing prices on homecoming games and games against top ranked opponents. Thus, Airbnb hosts do not systematically overestimate demand. Instead, the inverse relation between listing price increases and rental incomes is limited to games against rivals. 


\subsection{Competition}

We examine variation in competition across college towns using two metrics that capture the supply of Airbnb units. The first metric is the ratio of Airbnb units to all accommodations, defined as the number of Airbnb units divided by the number of Airbnb units plus the number of hotel rooms, and the second is the total number of Airbnb units, including units whose listing price does not change during the college football season. College towns with high (low) competition in the online rental market for accommodation are above (below) average for both these metrics.

In low-competition college towns, guests are price-takers and therefore accept higher listing prices on games against rivals. Consequently, the relatively high occupancy rate implies that the inverse unit-level relation between listing price increases and rental incomes is not predicted for units in low-competition college towns. However, low-competition college towns, by definition, have relatively few Airbnb units. Therefore, the small subset of units located in low-competition college towns facilitates a quasi placebo test.

The results in Table 8 confirm the importance of competition. In particular, the inverse relation between listing price increases and rental incomes that captures affiliation bias is limited to high-competition college towns where guests are not price-takers and therefore have the ability to avoid booking units whose hosts price discriminate on games against rivals. In contrast, while hosts in low-competition college towns also increase their listing prices on games against rivals, these increases are not suboptimal in terms of rental income.

\subsection{Distance to Stadium}

Although unit fixed effects are included in our empirical specifications, we estimate Equations (2) and (5) separately for units whose distance from the stadium is within 15 miles, 10 miles,

5 miles, and 1 mile, respectively. These separate estimations determine whether the inverse unit-level relation between listing price increases and rental incomes on games against rivals 
is sensitive to location. For example, hosts whose units are located closer to the stadium may be more devout fans of the home team or more concerned about damage.

The results in Table 9 illustrate the robustness of our main finding with respect to the location of Airbnb units. Specifically, the $\beta_{1}$ coefficients in Equation (2) are consistently positive and the $\beta_{3}$ coefficients are consistently negative in Equation (5) within each of the four distance subsets. Therefore, the inverse unit-level relation between listing price increases and rental incomes on games against rivals is insensitive to location.

\section{Financial Constraints}

Financial constraints can explain heterogeneity across the financial decisions of hosts (Campbell, 2006). To examine the impact of financial constraints, we collect the average credit utilization score of individual zip codes from Experian. The credit utilization score divides outstanding credit card debt by the total available credit, with the availability of credit reflecting host income. Zip codes where the average credit utilization score is above a college town's median credit utilization score are classified as having financially constrained hosts, while zip codes where the average credit utilization score is below this median are classified as having financially unconstrained hosts. ${ }^{16}$

A host's credit utilization score is determined by its credit card debt, not mortgage debt. Thus, financial constraints are not necessarily higher for hosts who utilize the tax deductibility of mortgage interest. Indeed, the average credit utilization score in a zip code is independent of the average mortgage payment. Zip-code level credit utilization scores range from 15 to 37 percent. As our next analysis assumes that hosts have a credit utilization score that parallels the average score near their Airbnb listing, we define professional hosts as those with more than one unit listed on Airbnb since every Airbnb host is assigned a unique host

\footnotetext{
${ }^{16}$ Results are similar if the median credit utilization score across all zip codes is used to distinguish financially constrained hosts from financially unconstrained hosts.
} 
identification number that is linked with each of their listings. Professionals comprise $13.7 \%$ of hosts and are responsible for managing $25.5 \%$ of the listings in our sample. Professional hosts likely have stronger incentives to maximize their rental income and may be more likely to reside at a different location than their Airbnb unit. ${ }^{17}$ Therefore, we remove 473 units where the financial constraints of professional hosts are ambiguous and limit our next analysis to non-professional hosts.

Equations (2) and (5) are re-estimated separately for financially constrained and financially unconstrained non-professional hosts. According to Table 10, financially unconstrained hosts have larger listing premiums on games against rivals than financially constrained hosts. In particular, according to Equation (2), the $\beta_{1}$ coefficient for financially unconstrained hosts is 25.378 and significant ( $t$-statistic of 3.823) compared to an insignificant 10.041 for financially constrained hosts. Thus, financially unconstrained hosts set higher listing price than those set by financially constrained hosts on games against rivals.

Moreover, in terms of rental income, Table 10 indicates that among financially unconstrained hosts, the $\beta_{3}$ coefficient in Equation (5) for the interaction between the Airbnb Listing Premium and the Rival indicator variable equals -0.430 ( $t$-statistic of -2.786). In contrast, the $\beta_{3}$ coefficient of 0.096 is insignificant among financially constrained hosts. A chi-squared statistic of 4.96 and a Z-statistic of 2.87 confirm the statistically significant difference between the $\beta_{3}$ coefficients for financially unconstrained hosts and financially constrained hosts at the $1 \%$ significance level.

The following in-sample averages summarize the economic implications of financial constraints. The average rental income of financially unconstrained hosts is similar to financially constrained hosts on games against highly ranked non-rival teams; $\$ 189.42$ compared to $\$ 187.23$, respectively. Thus, financial constraints do not affect the average rental income of Airbnb hosts on games against non-rival teams. However, on games against rival

\footnotetext{
${ }^{17}$ This expectation parallels the finance literature where mispricings attributable to behavioral biases are weaker for stocks with higher institutional investor ownership (lower retail investor ownership).
} 
teams, the average rental income of financially unconstrained hosts declines by over $20 \%$ to $\$ 149.24$, while the average rental income of financially constrained hosts is almost unchanged at $\$ 182.56$.

An additional analysis confirms that zip codes with higher average incomes have less financially constrained hosts. ${ }^{18}$ After estimating Equation (5) separately for high income and low income zip codes within each college town, an unreported robustness test finds a negative $\beta_{3}$ coefficient for high income zip codes and an insignificant $\beta_{3}$ coefficient for low income zip codes. Therefore, the inverse relation between listing price increases and rental incomes on games against rivals is limited to high income zip codes. Intuitively, animosity toward rival team affiliations is a luxury that low income hosts cannot afford to incorporate into their financial decisions.

As the majority of guest ratings on Airbnb are favorable, accommodating rival fans once or twice a year is unlikely to significantly lower a host's average rating. Consequently, the high listing premium on games against rivals is not compensation for the risk of receiving a poor review. Moreover, if rival fans did systematically assign lower ratings to their host, this risk would apply to all hosts. Therefore, the risk of being assigned a low rating by rival fans cannot explain variation in the Airbnb Listing Premium across financial constraints.

Finally, financially unconstrained hosts may be more likely to attend important home games. If financially unconstrained hosts are more likely to occupy their unit on these games, then blocking is predicted to be higher for financially unconstrained hosts. However, we find that blocking is insensitive to the financial constraints of hosts. ${ }^{19}$

Overall, financial constraints appear to reduce the impact of affiliation bias. This evidence is difficult to reconcile with the over-estimation of demand and the ability of learning to

\footnotetext{
${ }^{18}$ In contrast to income and credit utilization, mortgage payments exhibit less variability across the zip codes in a college town.

${ }^{19}$ In contrast to blocking, which essentially sets an infinite listing price, setting a high listing price on games against rivals provides the host with an opportunity to obtain the satisfaction of "price-gouging" a rival fan (despite lowering the host's expected rental income). This satisfaction is consistent with an affiliation bias against rival fans.
} 
mitigate affiliation bias since these alternative explanations require financially unconstrained hosts, whose low credit card balances are presumably a signal of financial sophistication, to be less sophisticated at setting listing prices.

\subsection{Learning}

Although Airbnb hosts have months to adjust the listing price of their unbooked units, and have access to the listing prices of other units as well as their status (booked or unbooked), we formally test the learning hypothesis by dividing the sample of Airbnb units in 2015, the second year of our sample, into those that were previously listed in 2014 (early hosts) and those that were not listed until 2015 (late hosts). The learning hypothesis associates early hosts in 2014 with greater learning, and therefore improved price setting, compared to late hosts.

Two caveats are relevant to this learning analysis; 1) learning is limited to a short time horizon, 2) visiting teams in 2014 will differ from those in 2015. More important, as Airbnb hosts intend to monetize existing real estate assets, the distinction between early and late hosts may be complicated by early hosts having a greater need for Airbnb rental income due to financial constraints instead of early hosts being more technologically savvy. Therefore, we condition on financial constraints within the early versus late host subsets.

The results in Table 11 do not support the hypothesis that learning mitigates affiliation bias. In particular, early financially unconstrained hosts have similar a $\beta_{3}$ coefficient from Equation (5) as late financially unconstrained hosts; -0.627 ( $t$-statistic of -2.074) versus -0.425 ( $t$-statistic of -2.310), respectively. Thus, we do not find evidence that the inverse unit-level relation between listing price increases and rental incomes is weaker for units listed in 2014 that are managed by early Airbnb hosts who have presumably learned more about the local rental market for accommodations.

Overall, instead of learning, financial constraints in conjunction with competition provide 
a channel through which affiliation bias affects the online market for rental accommodations. To clarify, inexperienced hosts setting prices in April for college football games later in October have several months to learn that their listing price is too high. This within-season learning is already accounted for by our original analysis that indicates affiliation bias is not mitigated by such learning. Instead, affiliation bias appears to arise from a taste-based preference that is impervious to learning.

\subsection{Shared Units}

Taste-based discrimination (Becker, 1957) can explain why Airbnb hosts are willing to accept lower rental incomes on games against rivals. Longhofer and Peters (2005) connect tastebased discrimination with self-selection in the real estate market. Motivated by this selfselection, we extend our empirical analysis to examine shared units on Airbnb.

The physical separation from the local population offered by entire units is important for visiting fans of the rival team but not for visiting fans of the home team. Thus, while visiting fans of the rival team are expected to avoid shared units in favor of entire units, shared units are suitable for visiting fans of the home team. Intuitively, although hosts cannot discriminate against guests by denying their bookings due to the Instant Book feature, the team affiliation of prospective guests can be inferred through their choice of either entire units or shared units. Thus, we predict that hosts of shared units do not have an affiliation bias against potential guests on games against rivals since these units are more likely to appeal to fans of the home team.

To examine the difference between entire units and shared units on Airbnb, we re-estimate Equation (2) for shared units. Table 12 reports that rival games are not associated with higher listing prices for shared units, regardless of financial constraints. The insignificant $\beta_{1}$ coefficient is consistent with shared units appealing to fans of the home team (alumni) rather than fans of the rival team. Observe that shared units are as likely to have a finan- 
cially unconstrained host as a financially constrained host, and the insignificance of the $\beta_{1}$ coefficient for shared units is not attributable to financial constraints.

\section{Robustness of the Rival Designations}

Any error in the classification of rival teams would weaken our empirical support for the joint-hypothesis that listing prices are higher and rental incomes are lower on games against rivals. Nevertheless, to ensure our classification of rival teams is capturing the mutual disdain between rival fans, we compile data on disorderly conduct violations and ejections (incidents) occurring at the stadium. ${ }^{20}$ Stadium incidents are available for a subset of colleges, typically state-funded institutions, that provide these statistics. We then estimate a team fixed effects model where the dependent variable is the number stadium incidents, and control for game characteristics such as the opponent's rank, home team's rank, homecoming, and whether the game began at 5pm or later (Prime Time Game).

In Table 13, our main variable of interest, Rival, has a positive coefficient of 15.607 ( $t$ statistic of 2.390) in the full specification. Thus, consistent with the mutual disdain between rival fans, there are more stadium incidents on games against rivals. In contrast, homecoming games, which are typically associated with a friendly opponent, are not associated with more stadium incidents as indicated by Homecoming's coefficient being negative or insignificant.

The positive coefficient of the Prime Time Game indicator variable is consistent with more important college football games eliciting stronger emotions. Similarly, higher ranked opponents lead to more stadium incidents. In particular, the Pre-Season Top 25 Opponent indicator variable has a positive coefficient, while Opponent's Rank has a negative coefficient. These coefficients are consistent with fans of higher ranked teams being more willing to travel with the visiting team, thereby increasing the likelihood that opposing fans interact at the

\footnotetext{
${ }^{20}$ Rees and Schnepel (2009) report increased crime surrounding the location of college football games, while Card and Dahl (2011) link unexpected losses in the National Football League to increased domestic violence.
} 
stadium.

Although several game and visiting team characteristics influence the number of stadium incidents, Table 2 reports that these characteristics do not increase Airbnb listing prices or hotel prices. Therefore, incidents at the stadium where opposing fans interact do not imply higher expected damage to hotel rooms or entire units on Airbnb that physically separate visitors from the local population.

\section{Expected Damage}

Several results indicate that the inverse relation between unit-level listing price increases and rental incomes on games against rivals does not result from a higher cost of providing accommodations to rival fans. Indeed, hosts receive insurance from Airbnb, and Airbnb hosts do not increase damage deposits on games against rivals. Airbnb hosts also rate guests, which provides an incentive for Airbnb guests to act responsibly.

Moreover, while financial constraints can reduce the influence of an affiliation bias on listing prices, the financial constraints of hosts are unlikely to influence their unit's exposure to damage. In particular, variation in Airbnb listing prices attributable to this host characteristic is unlikely to capture variation in unit-level exposure to damage. Airbnb hosts can also block their unit from being booked to prevent damage. However, Airbnb hosts are not more likely to block their unit on games against rivals, and blocking is insensitive to host financial constraints. Moreover, providing accommodation on home games against rival teams does not lead to increased blocking in the subsequent week. This increase in blocking would be needed to facilitate repairs if guests were more likely to damage units on games against rivals.

The previous results for stadium incidents cannot explain the high listing prices on games against rivals. Indeed, homecoming games are associated with high hotel prices but fewer stadium incidents. Similarly, games against a higher ranked opponent have more stadium 
incidents but lower listing prices than games against rivals. Therefore, incidents that arise from interactions between opposing fans at the stadium do not imply greater damage for Airbnb units (and hotel rooms) that physically separate fans of the rival team from the local population.

\section{Conclusion}

We find evidence that an affiliation bias against fans of a rival college team lead Airbnb host to set listing prices that are too high. Specifically, listing price increases on games against rival teams lower the rental incomes of Airbnb hosts. This inverse relation between listing price increases and rental income is concentrated among financially unconstrained hosts. Thus, financial constraints appear to reduce the impact of affiliation bias on household financial decisions.

While our results are specific to rental accommodations in college towns, they highlight an important issue in the rapidly expanding sharing economy. The prices set by hosts may differ substantially from those set by corporations due to affiliation bias. Indeed, our results identify the importance of professional management in "rationalizing" the sharing economy.

As the bias we study involve rival affiliations, our study sheds light on a subtle form of discrimination that differs from discrimination based on ethnicity and gender. Moreover, in the competitive market for short-term accommodation that is characterized by low search costs and low barriers to entry, attempts to discriminate lead to losses rather than gains. Thus, our results are consistent with Becker (1957). 


\section{References}

Agarwal, S., I. Ben-David, and V. Yao, 2017, Systematic mistakes in the mortgage market and lack of financial sophistication. Journal of Financial Economics 123, 42-58.

Ahmed, A., L. Andersson, and M. Hammarstedt, 2010, Can discrimination in the housing market be reduced by increasing the information about the applicants? Land Economics 86, 79-90.

Ahmed, A., L. Andersson, and M. Hammarstedt, 2008, Are lesbians discriminated against in the rental housing market? Evidence from a correspondence testing experiment. Journal of Housing Economics 17, 234-238.

Ahmed, A., and M. Hammarstedt, 2008, Discrimination in the rental housing market: A field experiment on the internet. Journal of Urban Economics 64, 362-372.

Barron, K., E. Kung, and D. Proserpio, 2020, The effect of home-sharing on house prices and rents: Evidence from Airbnb. Forthcoming in Marketing Science.

Bartlett, R., A. Morse, R. Stanton, and N. Wallace, 2019, Consumer-lending discrimination in the FinTech era. NBER Working Paper 25943.

Becker, G., 1957, The Economics of Discrimination. University of Chicago Press.

Bertrand, M., and S. Mullainathan, 2004, Are Emily and Greg more employable than Lakisha and Jamal? A field experiment on labor market discrimination. American Economic Review 94, 991-1013.

Campbell, J., 2006, Household finance. Journal of Finance 61, 1553-1604.

Card, D., and G. Dahl, 2011, Family violence and football: The effect of unexpected emotional cues on violent behavior. Quarterly Journal of Economics 126, 103-143. 
Carlsson, M., and S. Eriksson, 2014, Discrimination in the rental market for apartments. Journal of Housing Economics 23, 41-54.

Cikara, M., M. Botvinick, and S. Fiske, 2011, Us versus them: Social identity shapes neural responses to intergroup competition and harm. Psychological Science 22, 306-313.

Corgel, J., C. Liu, and R. White, 2015, Determinants of hotel property prices. Journal of Real Estate Finance and Economics 51, 415-439.

Corwin, S., S. Larocquea, and M. Stegemoller, 2017, Investment banking relationships and analyst affiliation bias: The impact of the global settlement on sanctioned and nonsanctioned banks. Journal of Financial Economics 124, 614-631.

Edelman, B., M. Luca, and D. Svirsky, 2017, Racial discrimination in the sharing economy: Evidence from a field experiment. American Economic Journal: Applied Economics 9, 1-22.

Edmans, A., D. García, and Ø. Norli, 2007, Sports sentiment and stock returns. Journal of Finance 62, 1967-1998.

Ge, Y., C. Knittel, D. MacKenzie, and S. Zoepf, 2016, Racial and gender discrimination in transportation network companies. NBER Working Paper 22776.

Horn, K, and M. Merante, 2017, Is home sharing driving up rents? Evidence from Airbnb in Boston. Journal of Housing Economics 38, 14-24.

King, T., and P. Mieszkowski, 1973, Racial discrimination, segregation, and the price of housing. Journal of Political Economy 81, 590-606.

Longhofer, S., and S. Peters, 2005, Self-selection and discrimination in credit markets. Real Estate Economics 33, 237-268.

Lu, F., and H. Munneke, 2017, Gender equality in mortgage lending. Real Estate Economics $45,1-47$. 
Puig, S., and A. Strezhev, 2017, Affiliation bias in arbitration: An experimental approach. Journal of Legal Studies 46, 371-398.

Quintanar, S., C. Deck, J. Reyes, and S. Sarangi, 2015, You are close to your rival, and everybody hates a winner: A study of rivalry in college football. Economic Inquiry 53, 1908-1918.

Rees, D., and K. Schnepel, 2009, College football games and crime. Journal of Sports Economics 10, 68-87.

Sheppard, S., and A. Udell, 2018, Do Airbnb properties affect house prices? Working Paper. 
This article is protected by copyright. All rights reserved. 


\section{Figure 1: Difference in Listing Premium: Airbnb - Hotels}

This figure illustrates the difference in the listing premium between Airbnb units and hotel rooms. The Airbnb listing premium is computed at the unit level as the listing price on a specific game, such as homecoming, minus the unit's average listing price across all home games in the same season. The hotel listing premium is computed at the college level as the average hotel price on a specific game minus the average hotel price across all home games in the same season.

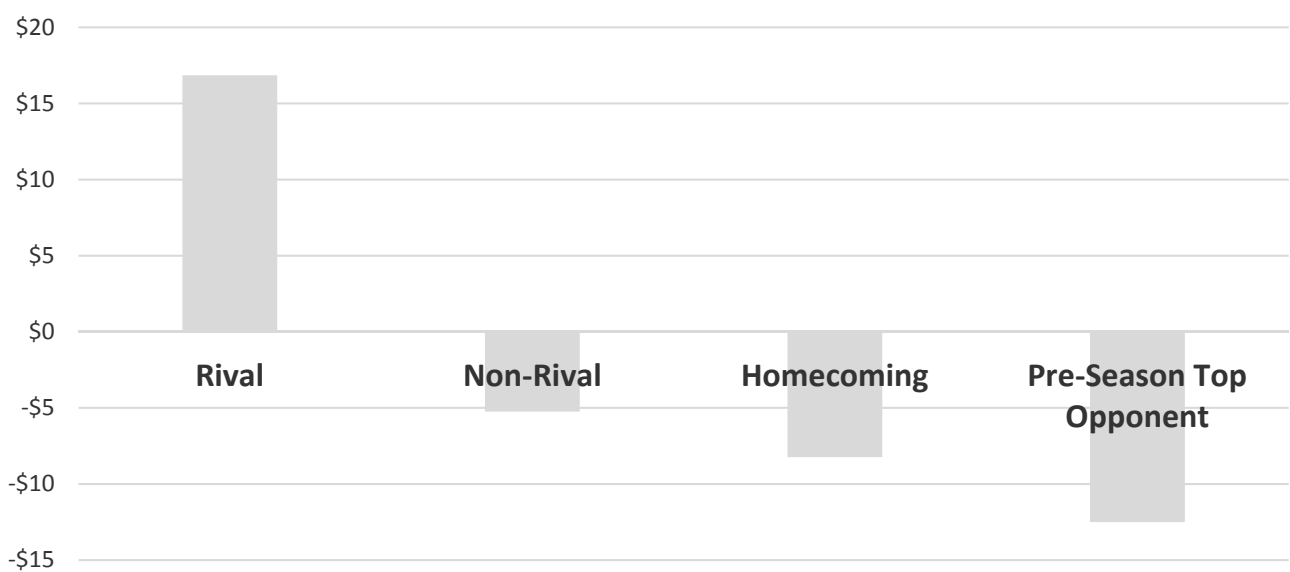




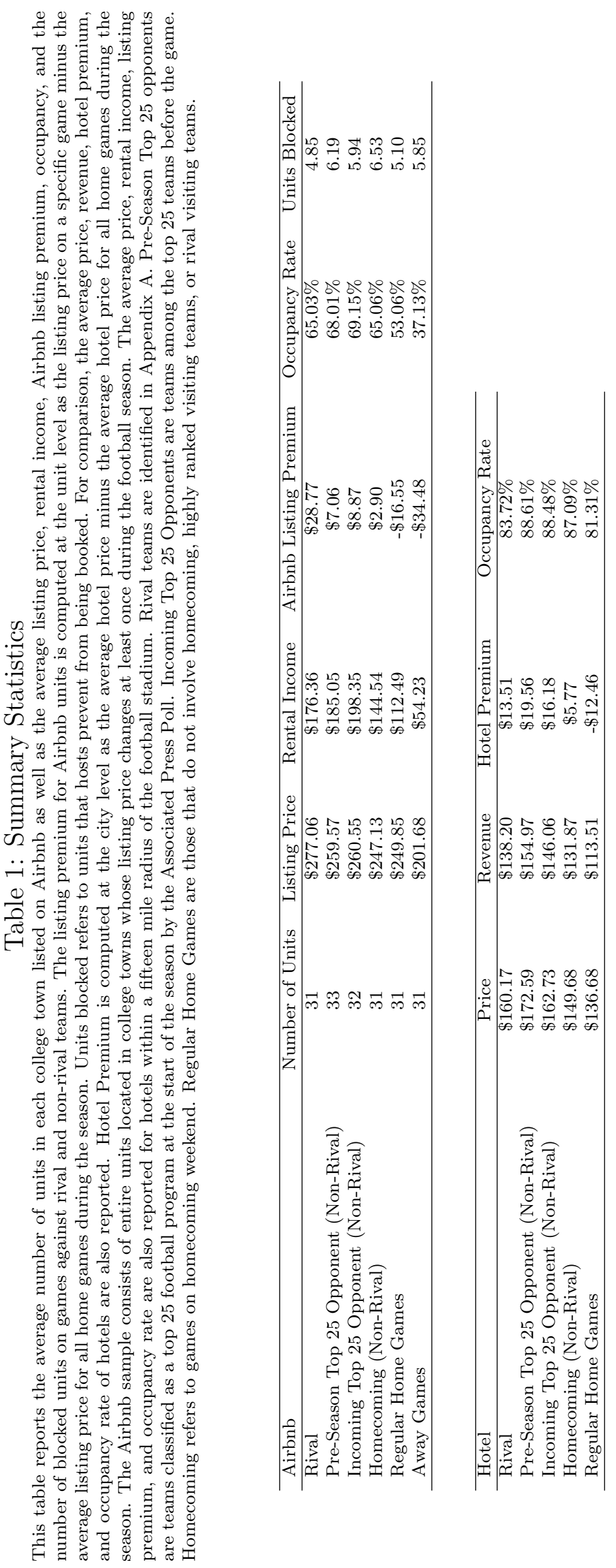

This article is protected by copyright. All rights reserved. 


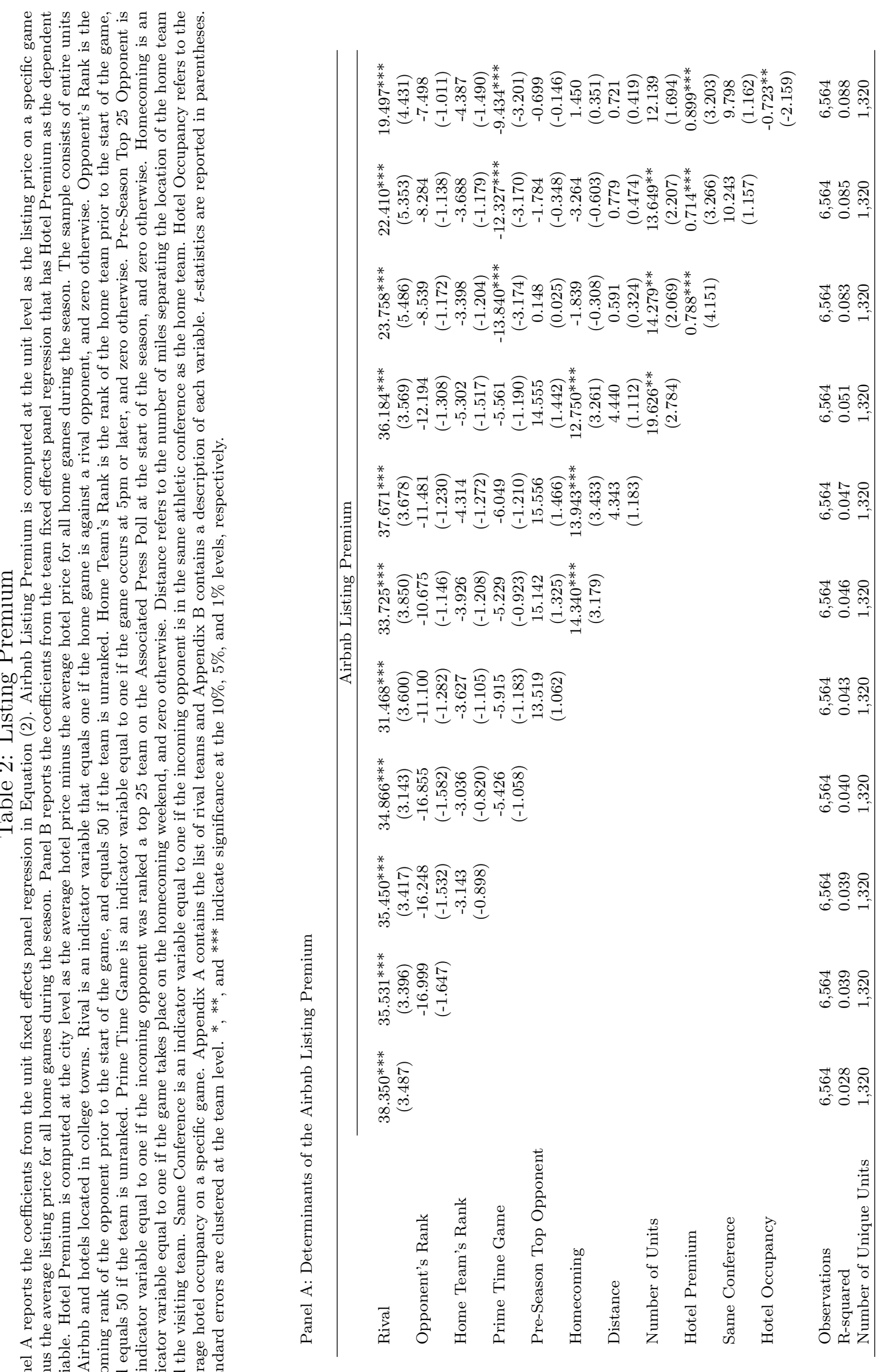

This article is protected by copyright. All rights reserved. 


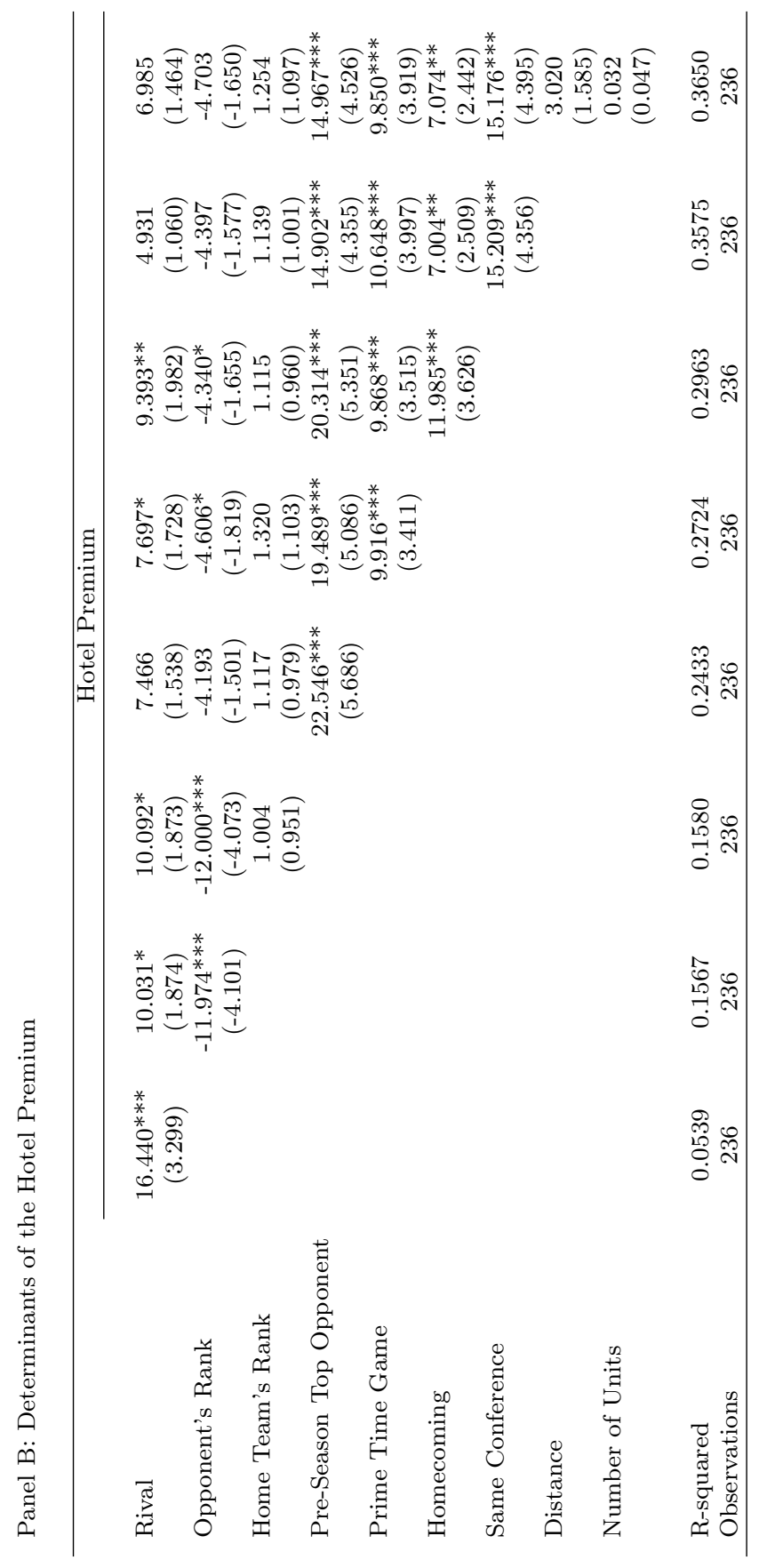

This article is protected by copyright. All rights reserved. 


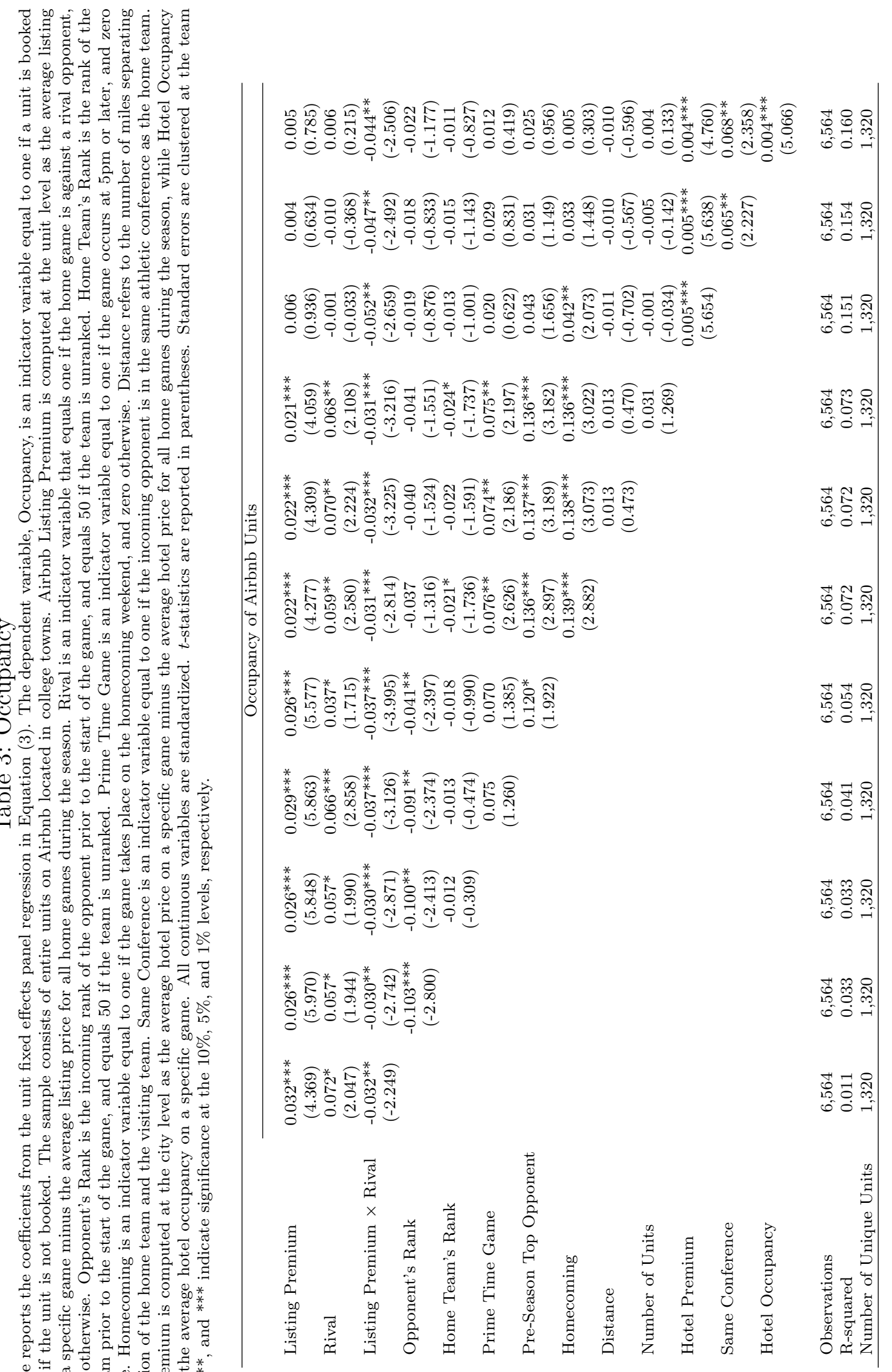

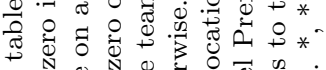

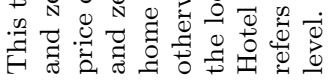


g.

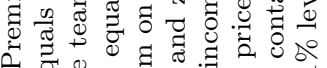

00 o 0 .

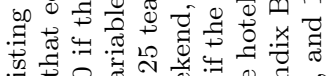

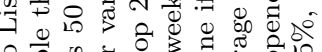

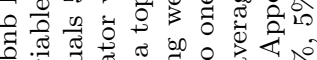

势

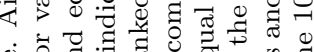

융

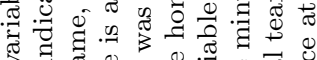

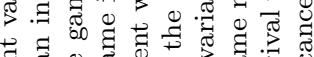

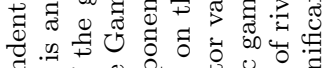

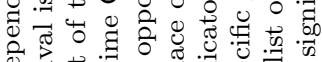

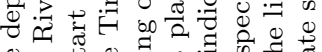

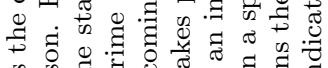

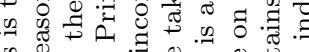

䑧

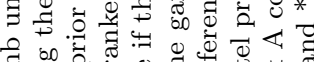

$\exists .00$

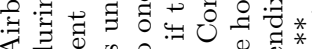

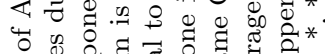

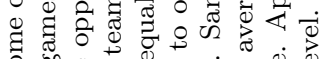

它

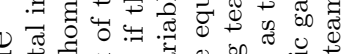

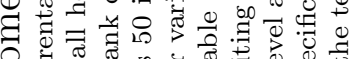

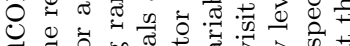

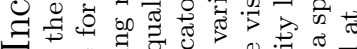

శ

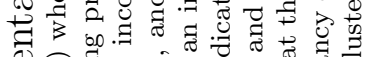

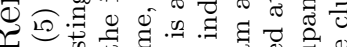

然

$\ddot{\forall} \cdot \overrightarrow{0}$.

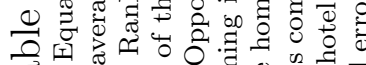

西.

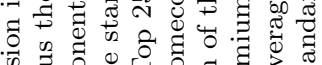

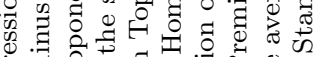

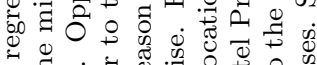

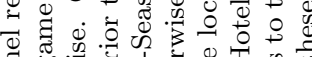

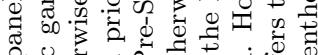

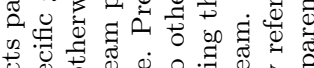

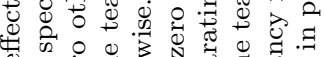

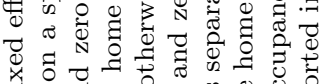

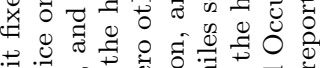

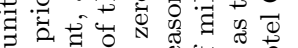

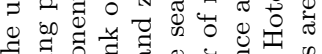

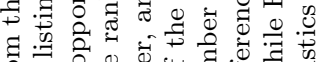

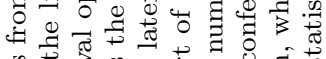

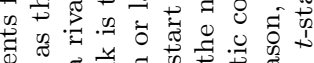

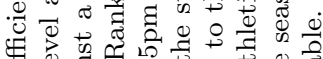

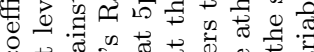

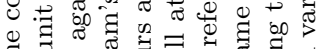

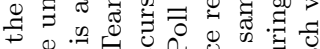

क力

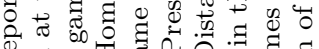

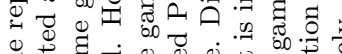

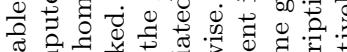

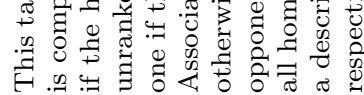

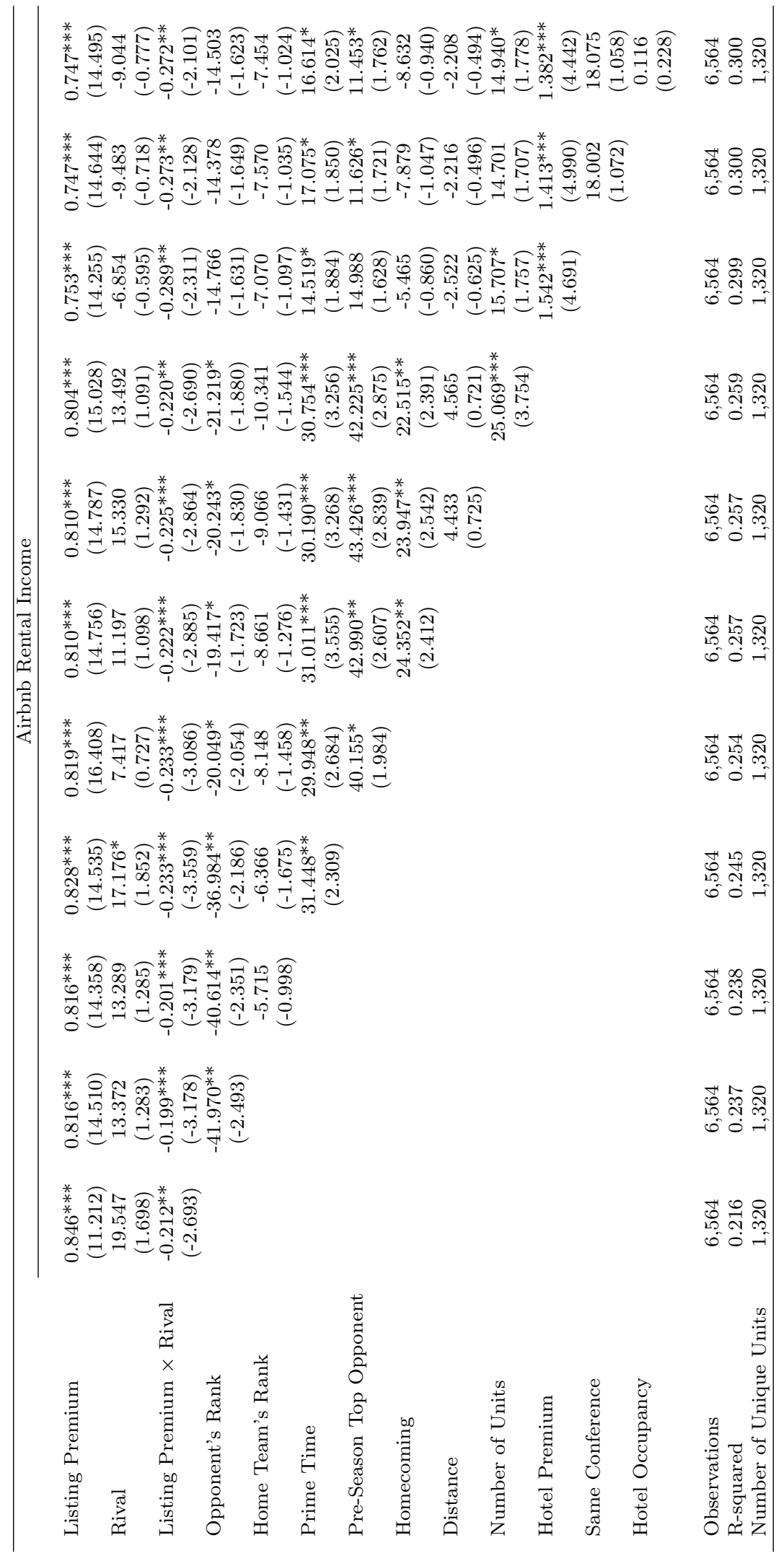

This article is protected by copyright. All rights reserved. 


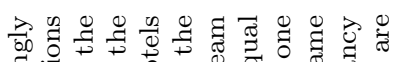

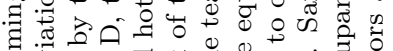

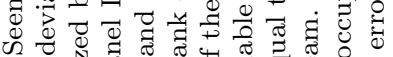

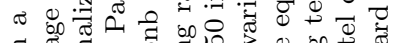

घ

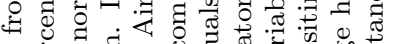

क

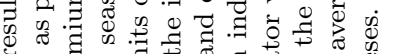

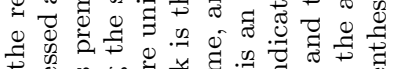

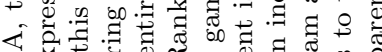

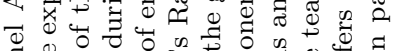

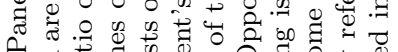

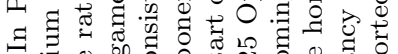

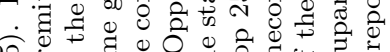

过

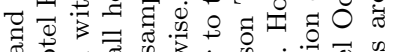

ลิ

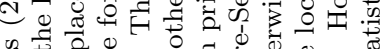

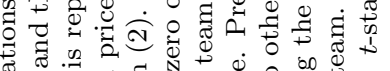

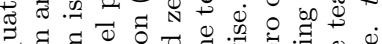

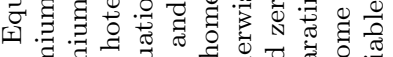

\&

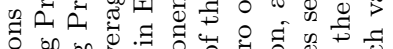

w .

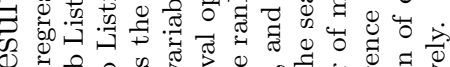

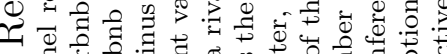

厄゙

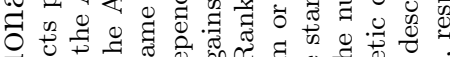

.

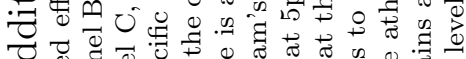

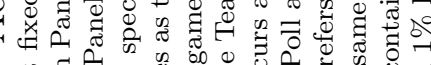

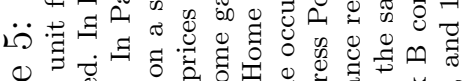

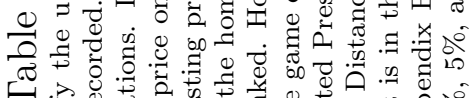

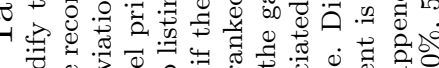

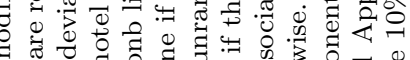

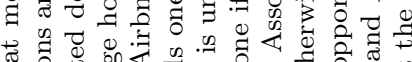

落.

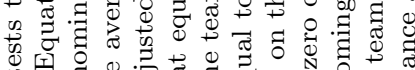

屯 I I

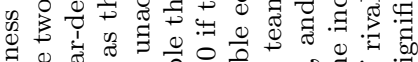

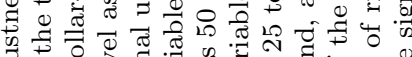

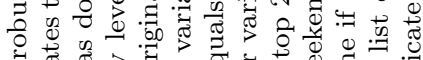

\&

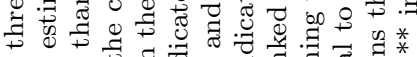

a D

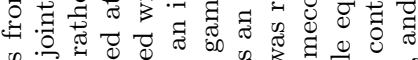

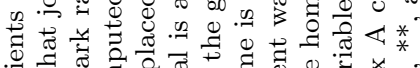

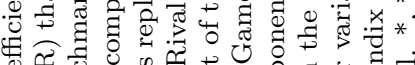

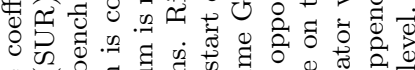

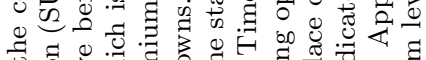

+ . :

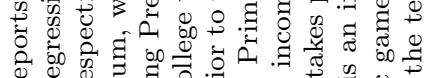

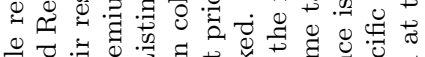

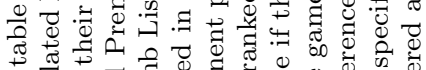

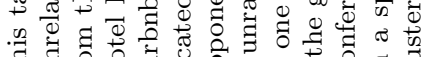

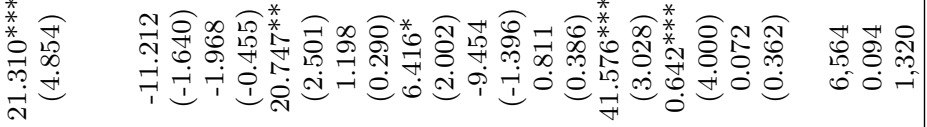

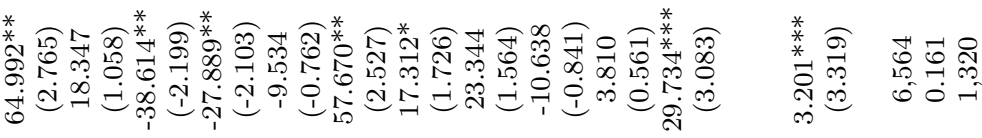

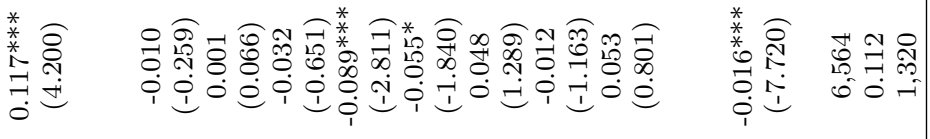

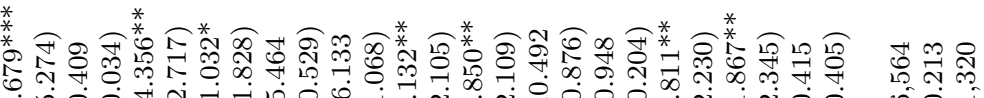

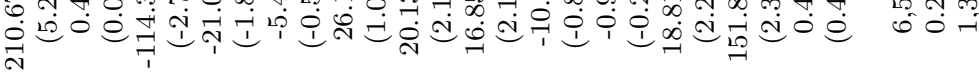

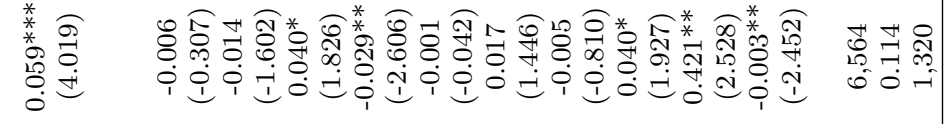

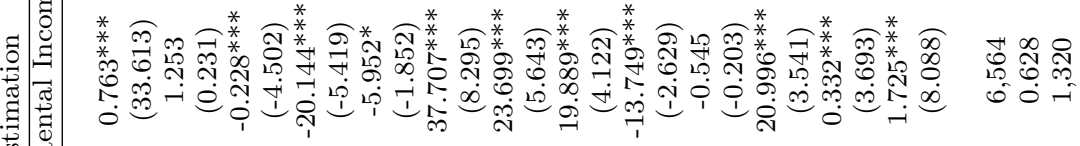

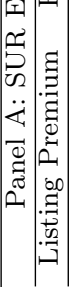

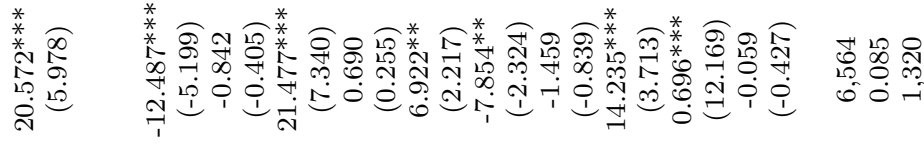

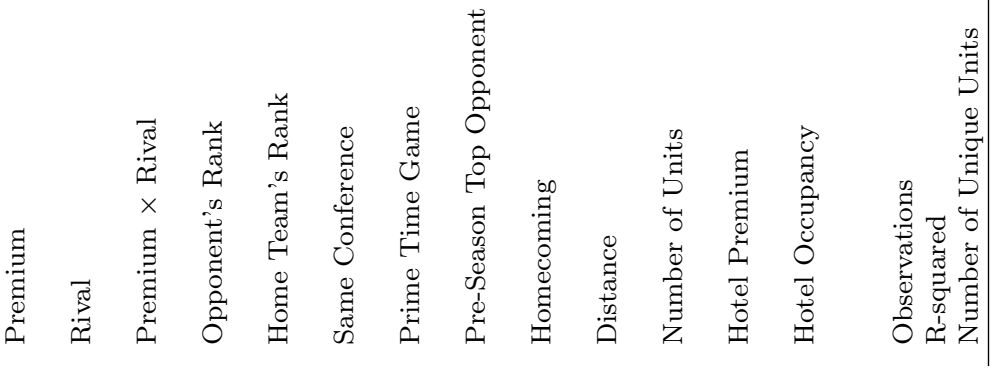

This article is protected by copyright. All rights reserved. 
Table 6: Residual Listing Premium

This table reports the coefficients from the unit fixed effects panel regression where the rental income of Airbnb units is the dependent variable. Residual Listing Premium is computed by regressing the Airbnb Listing Premium onto the Hotel Premium. Airbnb Listing Premium is computed at the unit level as the listing price on a specific game minus the average listing price for all home games during the season. Hotel Premium is computed at the city level as the average hotel price on a specific minus the average hotel price for all home games during the season. Rival is an indicator variable that equals one if the home game is against a rival opponent, and zero otherwise. Opponent's Rank is the incoming rank of the opponent prior to the start of the game, and equals 50 if the team is unranked. Home Team's Rank is the rank of the home team prior to the start of the game, and equals 50 if the team is unranked. Prime Time Game is an indicator variable equal to one if the game occurs at $5 \mathrm{pm}$ or later, and zero otherwise. Pre-Season Top 25 Opponent is an indicator variable equal to one if the incoming opponent was ranked a top 25 team on the Associated Press Poll at the start of the season, and zero otherwise. Homecoming is an indicator variable equal to one if the game takes place on the homecoming weekend, and zero otherwise. Distance refers to the number of miles separating the location of the home team and the visiting team. Same Conference is an indicator variable equal to one if the incoming opponent is in the same athletic conference as the home team. Hotel Occupancy refers to the average hotel occupancy on a specific game. Appendix A contains the list of rival teams and Appendix B contains a description of each variable. $t$-statistics are reported in parentheses. Standard errors are clustered at the team level. ${ }^{*}, * *$, and $* * *$ indicate significance at the $10 \%, 5 \%$, and $1 \%$ levels, respectively.

\begin{tabular}{|c|c|c|}
\hline & Airbnb Listing Premium & Rental Income \\
\hline Hotel Premium & $\begin{array}{c}0.891^{* * *} \\
(4.472)\end{array}$ & \\
\hline Residual Listing Premium & & $\begin{array}{c}0.822^{* * *} \\
(9.387)\end{array}$ \\
\hline Rival & & $\begin{array}{l}-13.529 \\
(-1.103)\end{array}$ \\
\hline Residual Listing Premium $\times$ Rival & & $\begin{array}{r}-0.214^{* *} \\
(-2.031)\end{array}$ \\
\hline Opponent's Rank & & $\begin{array}{l}-16.204 \\
(-1.675)\end{array}$ \\
\hline Home Team's Rank & & $\begin{array}{l}-6.120 \\
(-0.818)\end{array}$ \\
\hline Prime Time Game & & $\begin{array}{l}15.997^{*} \\
(1.834)\end{array}$ \\
\hline Pre-Season Top Opponent & & $\begin{array}{l}11.176 \\
(1.694)\end{array}$ \\
\hline Homecoming & & $\begin{array}{l}-8.847 \\
(-0.883)\end{array}$ \\
\hline Distance & & $\begin{array}{l}-2.961 \\
(-0.619)\end{array}$ \\
\hline Number of Units & & $\begin{array}{l}14.156 \\
(1.617)\end{array}$ \\
\hline Hotel Premium & & $\begin{array}{c}2.016^{* * *} \\
(5.365)\end{array}$ \\
\hline Same Conference & & $\begin{array}{l}19.390 \\
(1.107)\end{array}$ \\
\hline Hotel Occupancy & & $\begin{array}{c}0.179 \\
(0.333)\end{array}$ \\
\hline Observations & 6,564 & 6,564 \\
\hline R-squared & 0.061 & 0.283 \\
\hline Number of Unique Units & 1,320 & 1,320 \\
\hline
\end{tabular}

This article is protected by copyright. All rights reserved. 


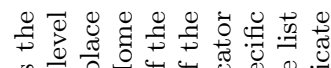

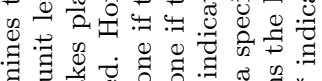

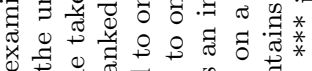

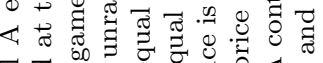

马

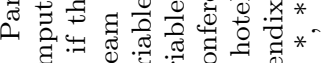

웅

西. .

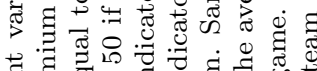

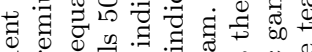

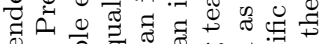

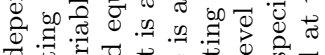

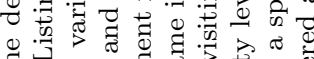

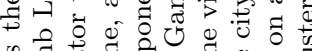

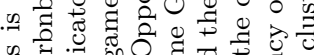

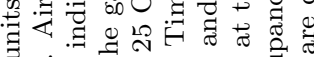

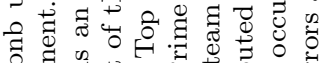

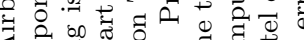

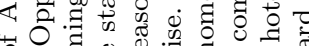

응

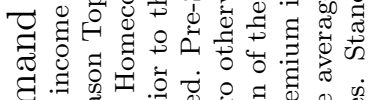

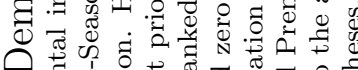

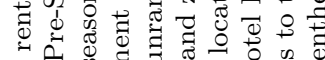

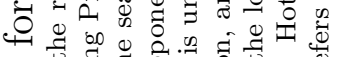

s.

o

$F$

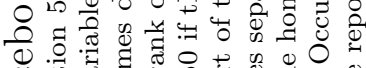

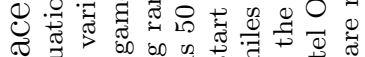

二

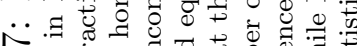

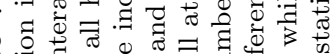

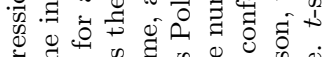

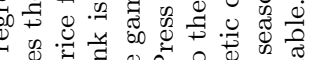

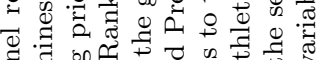

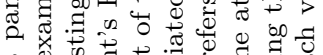

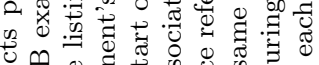

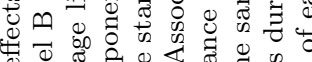

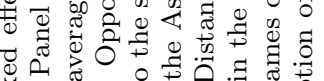

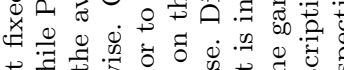

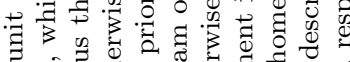

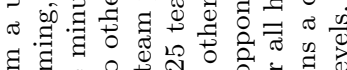

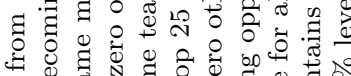

no

무의

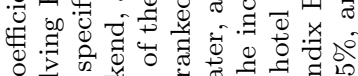

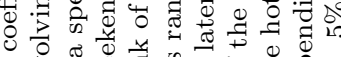

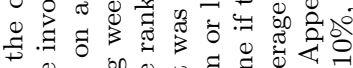

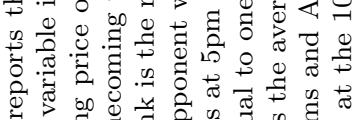

응.:

ब记

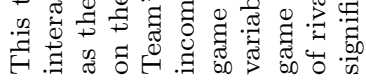

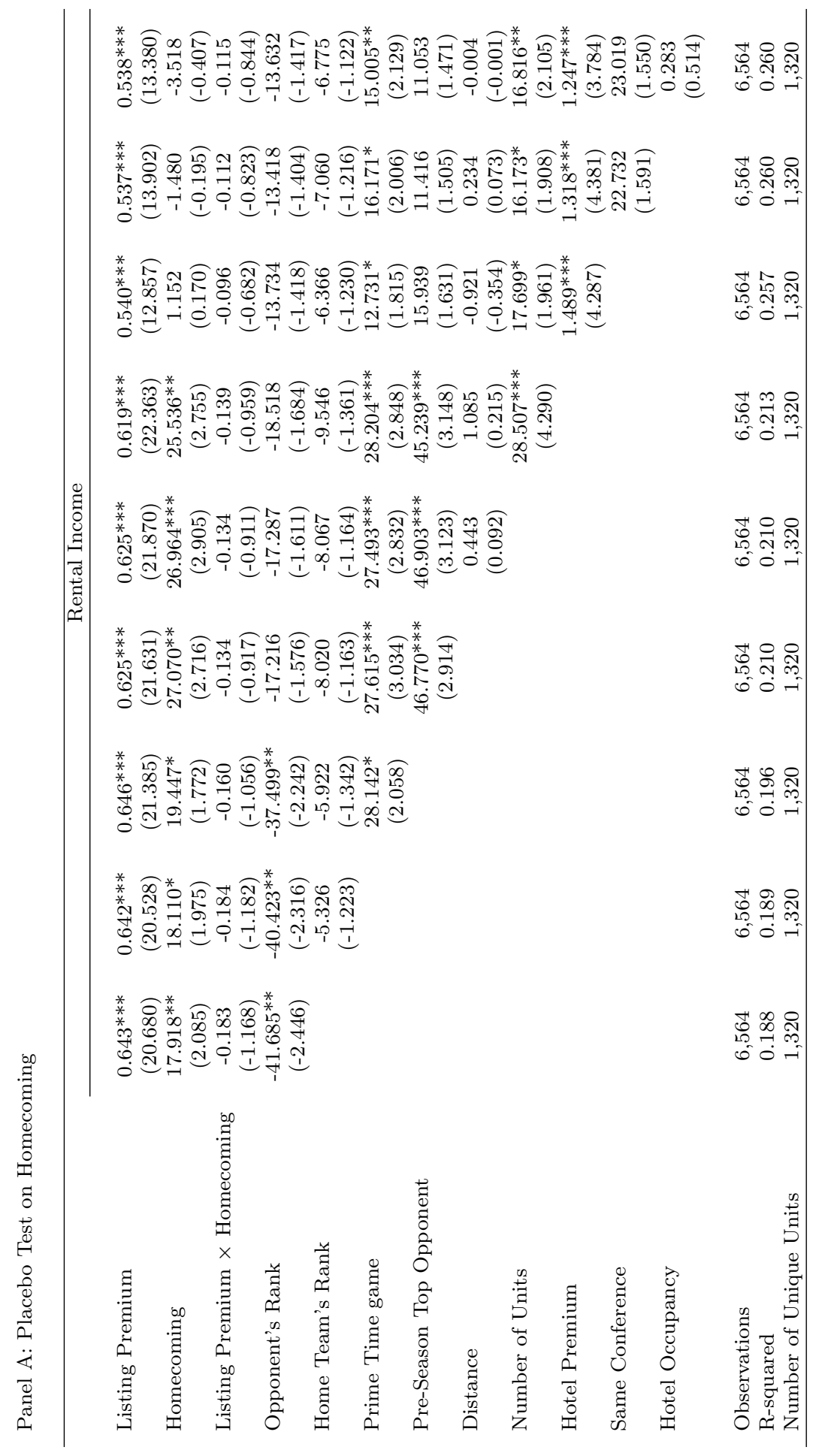

This article is protected by copyright. All rights reserved. 


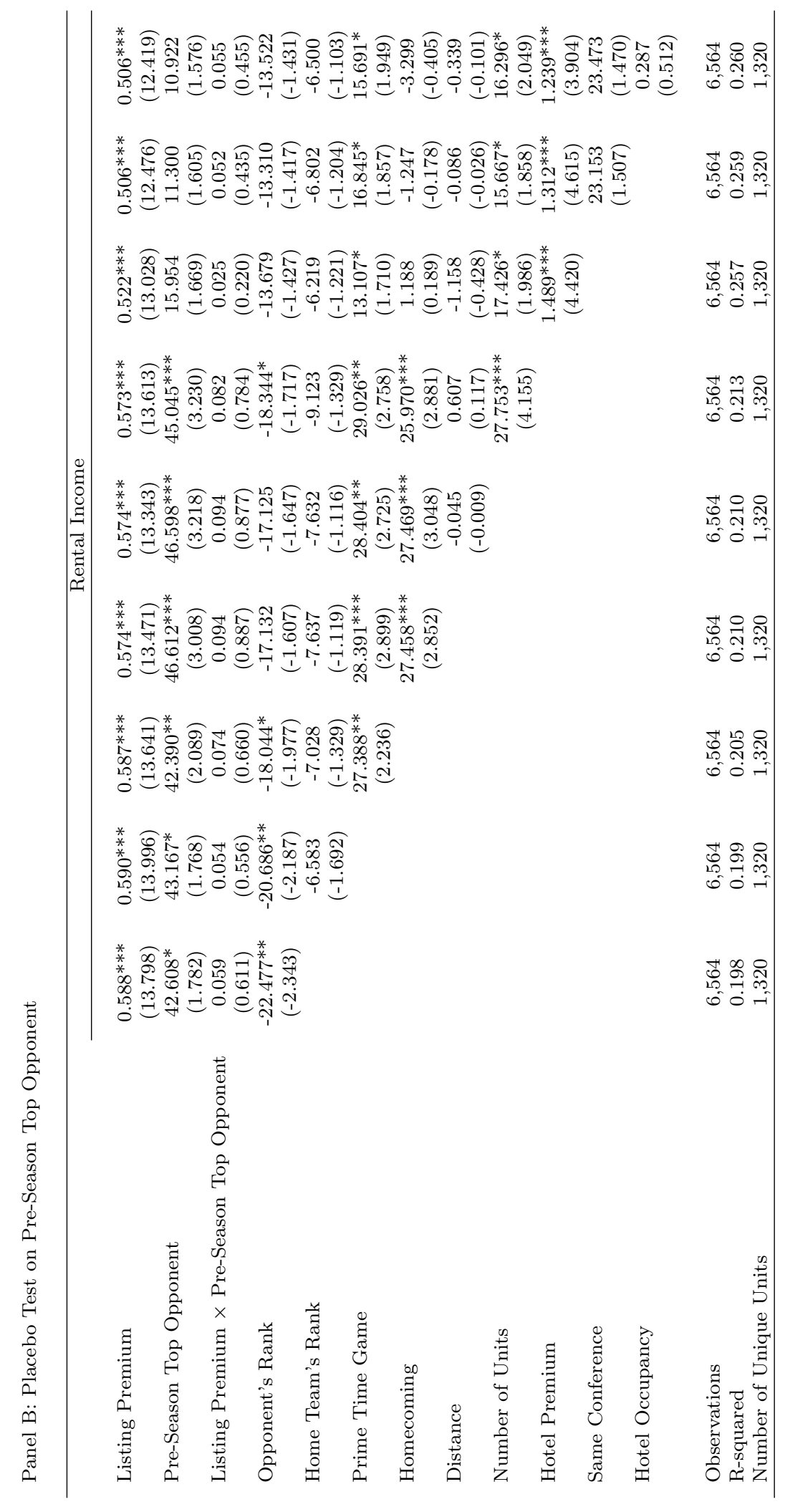

This article is protected by copyright. All rights reserved. 


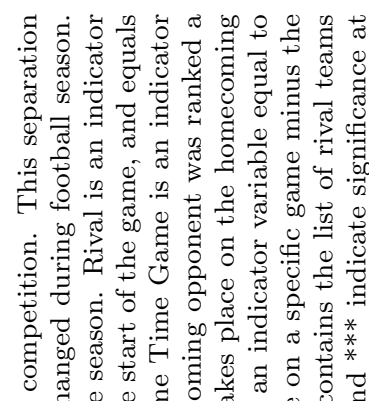

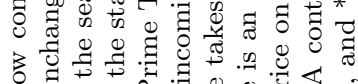

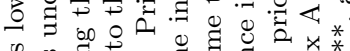

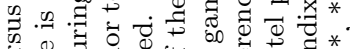

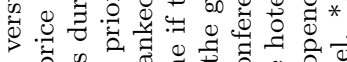

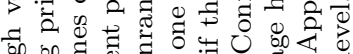

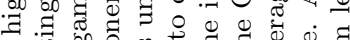
$\circ$. 00 .

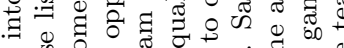

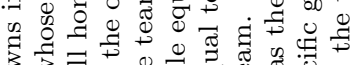

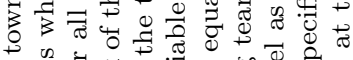

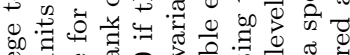

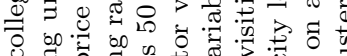
을

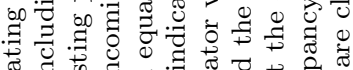

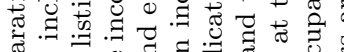
胥.

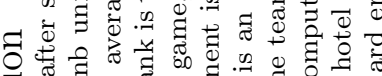

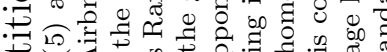

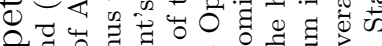
西萠

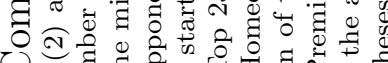

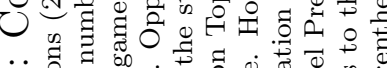

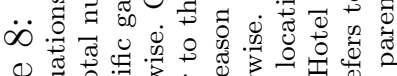

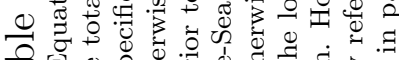

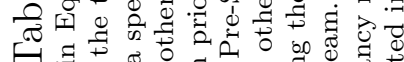
ตี W

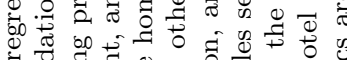

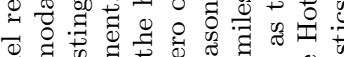

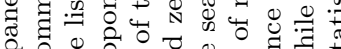
कू

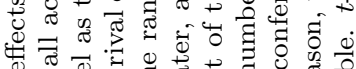

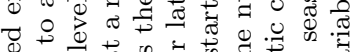

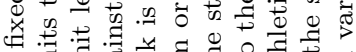

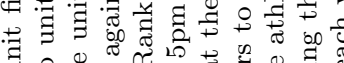

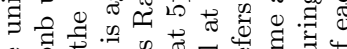

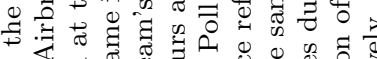

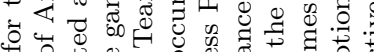

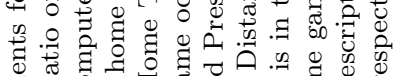

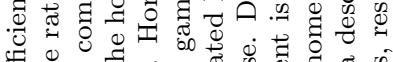

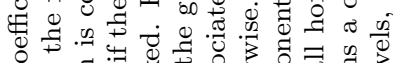

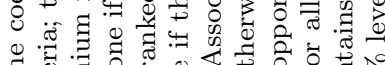

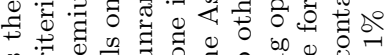

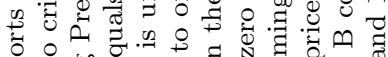

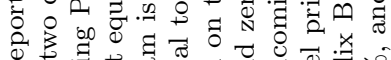

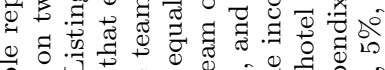

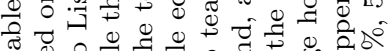

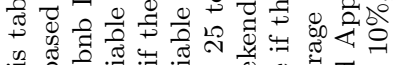

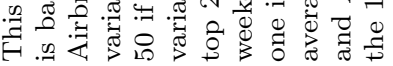

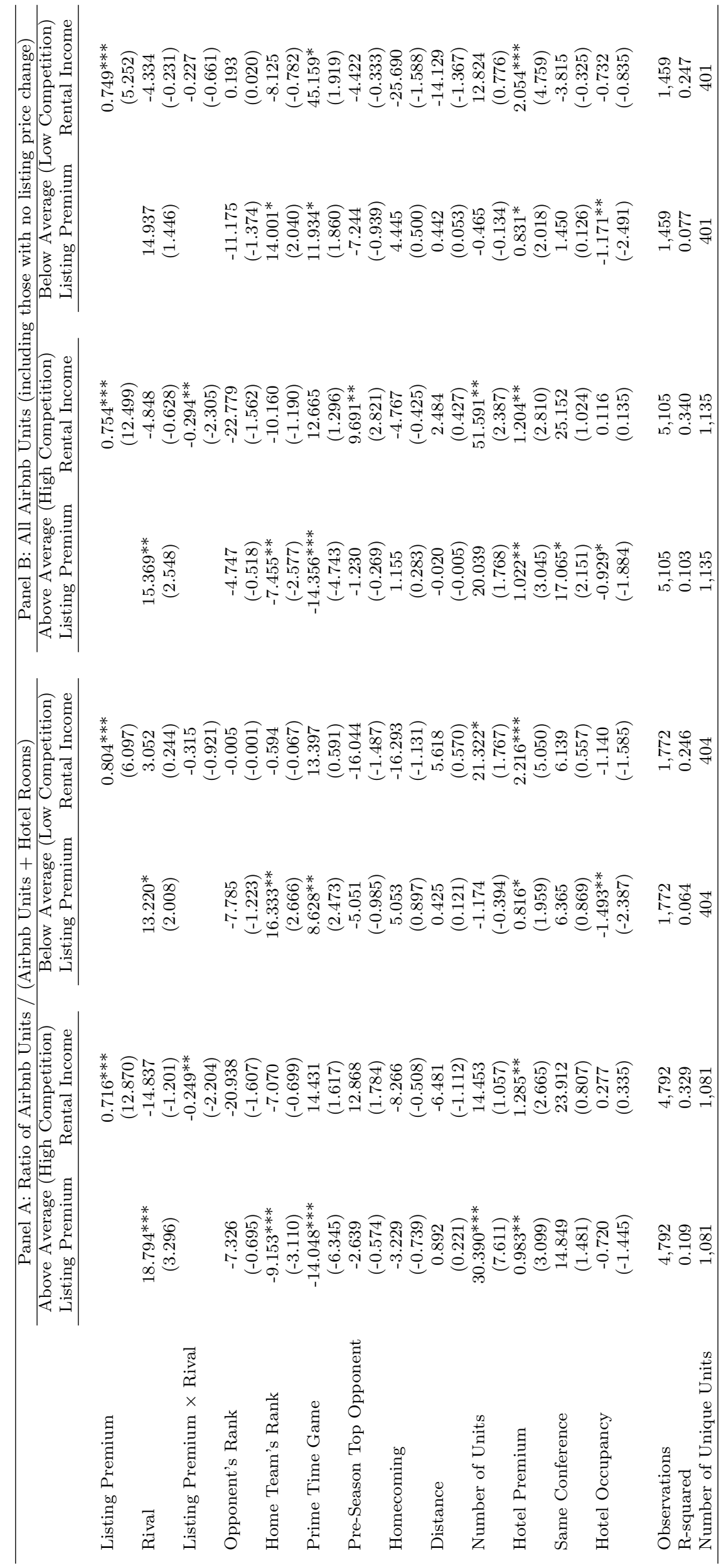




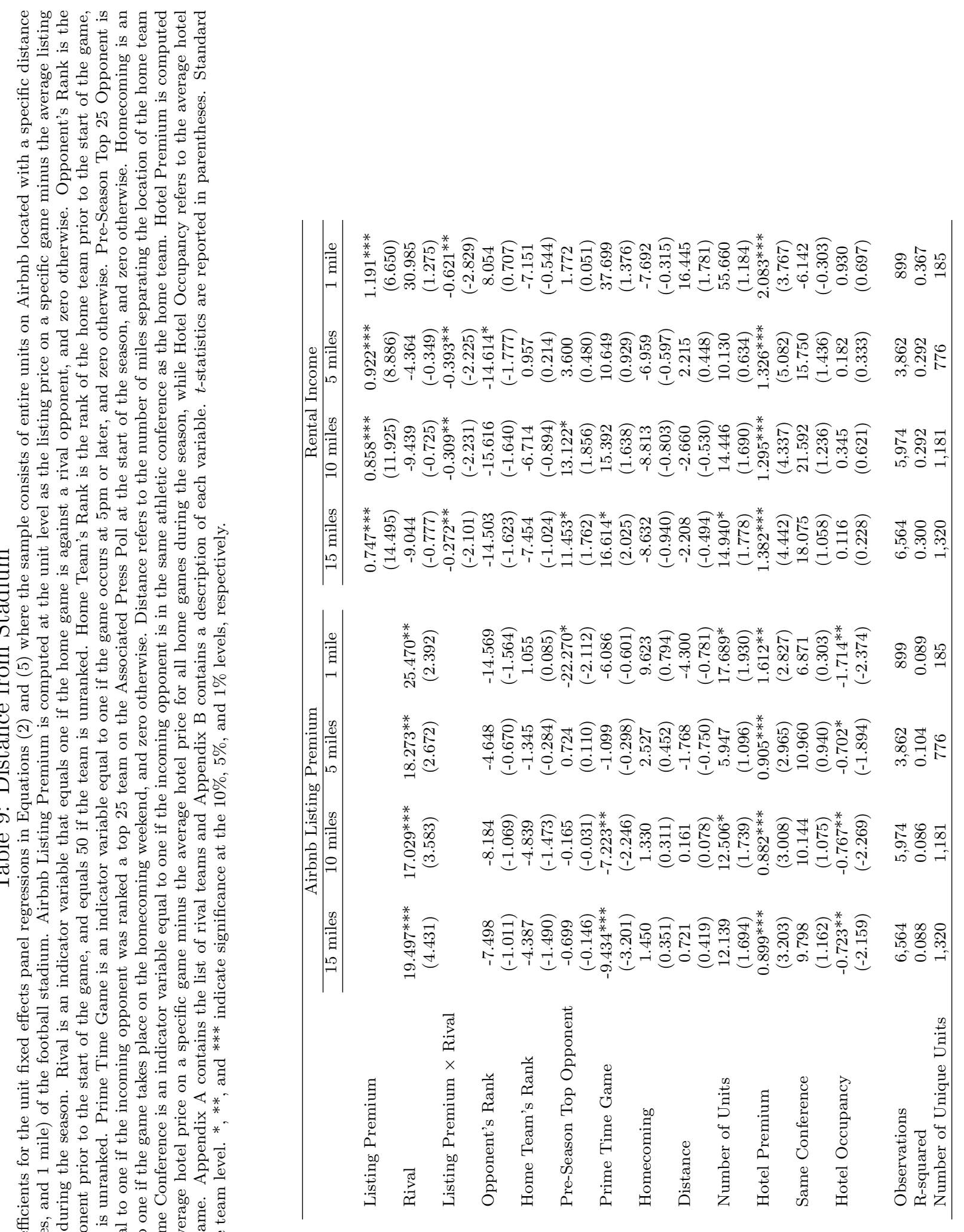

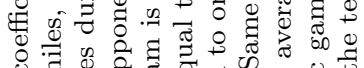

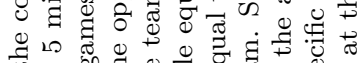

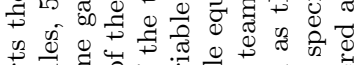

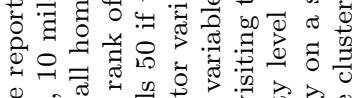

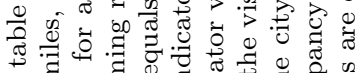

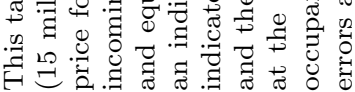


Table 10: Financial Constraints

This reports the coefficients from the unit fixed effects panel regressions in Equations (2) and (5) for non-professional hosts that have only one unit listed on Airbnb. A low credit utilization score corresponds with financially unconstrained hosts, while a high credit utilization score corresponds with financially constrained hosts. Airbnb Listing Premium is computed at the unit level as the listing price on a specific game minus the average listing price for all home games during the season. Rival is an indicator variable that equals one if the home game is against a rival opponent, and zero otherwise. Opponent's Rank is the incoming rank of the opponent prior to the start of the game, and equals 50 if the team is unranked. Home Team's Rank is the rank of the home team prior to the start of the game, and equals 50 if the team is unranked. Prime Time Game is an indicator variable equal to one if the game occurs at $5 \mathrm{pm}$ or later, and zero otherwise. Pre-Season Top 25 Opponent is an indicator variable equal to one if the incoming opponent was ranked a top 25 team on the Associated Press Poll at the start of the season, and zero otherwise. Homecoming is an indicator variable equal to one if the game takes place on the homecoming weekend, and zero otherwise. Distance refers to the number of miles separating the location of the home team and the visiting team. Same Conference is an indicator variable equal to one if the incoming opponent is in the same athletic conference as the home team. Hotel Premium is computed at the city level as the average hotel price on a specific game minus the average hotel price for all home games during the season, while Hotel Occupancy refers to the average hotel occupancy on a specific game. Appendix A contains the list of rival teams and Appendix B contains a description of each variable. $t$-statistics are reported in parentheses. Standard errors are clustered at the team level. ${ }^{*},{ }^{* *}$, and $* * *$ indicate significance at the $10 \%, 5 \%$, and $1 \%$ levels, respectively.

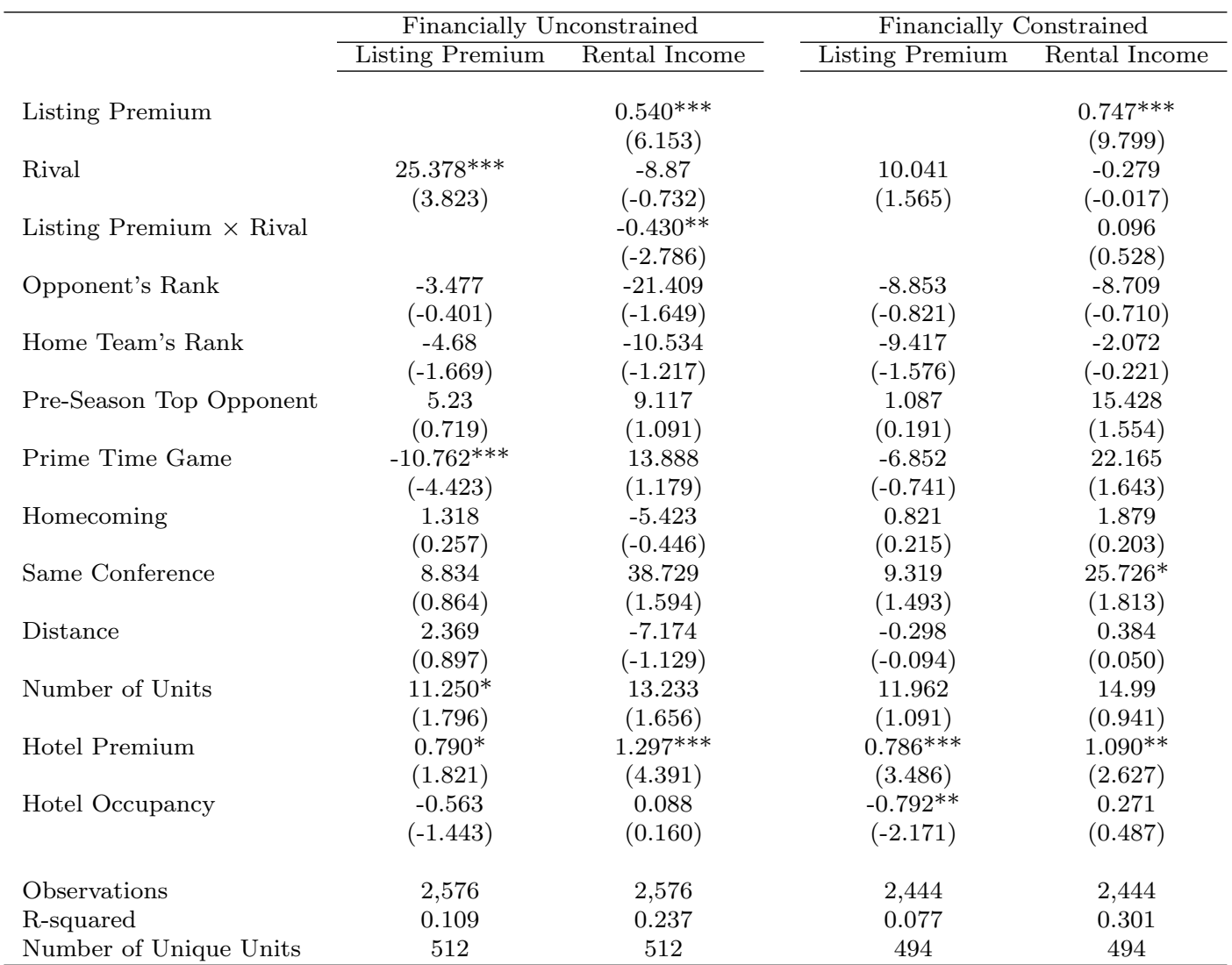

This article is protected by copyright. All rights reserved. 


\section{Table 11: Learning}

This table reports the coefficients from the unit fixed effects panel regressions in Equation (5) based on units in 2015. The sample of units is divided into two categories; those that were first listed in 2014 (early hosts) versus those that were first listed in 2015 (late hosts). Units listed in 2014 are associated with greater learning than those listed in 2015. A low credit utilization score corresponds with financially unconstrained hosts, while a high credit utilization score corresponds with financially constrained hosts. Airbnb Listing Premium is computed at the unit level as the listing price on a specific game minus the average listing price for all home games during the season. Rival is an indicator variable that equals one if the home game is against a rival opponent, and zero otherwise. Opponent's Rank is the incoming rank of the opponent prior to the start of the game, and equals 50 if the team is unranked. Home Team's Rank is the rank of the home team prior to the start of the game, and equals 50 if the team is unranked. Prime Time Game is an indicator variable equal to one if the game occurs at 5pm or later, and zero otherwise. Pre-Season Top 25 Opponent is an indicator variable equal to one if the incoming opponent was ranked a top 25 team on the Associated Press Poll at the start of the season, and zero otherwise. Homecoming is an indicator variable equal to one if the game takes place on the homecoming weekend, and zero otherwise. Distance refers to the number of miles separating the location of the home team and the visiting team. Same Conference is an indicator variable equal to one if the incoming opponent is in the same athletic conference as the home team. Hotel Premium is computed at the city level as the average hotel price on a specific game minus the average hotel price for all home games during the season, while Hotel Occupancy refers to the average hotel occupancy on a specific game. Appendix A contains the list of rival teams and Appendix B contains a description of each variable. $t$-statistics are reported in parentheses. Standard errors are clustered at the team level. *, **, and *** indicate significance at the $10 \%, 5 \%$, and $1 \%$ levels, respectively.

\begin{tabular}{|c|c|c|c|c|}
\hline & \multicolumn{4}{|c|}{ Rental Income } \\
\hline & \multicolumn{2}{|c|}{ High Learning (Early Hosts) } & \multicolumn{2}{|c|}{ Low Learning (Late Hosts) } \\
\hline & Unconstrained & Constrained & Unconstrained & Constrained \\
\hline Listing Premium & $\begin{array}{c}0.685^{* * *} \\
(3.359)\end{array}$ & $\begin{array}{c}0.824^{* * *} \\
(8.591)\end{array}$ & $\begin{array}{c}0.663^{* * *} \\
(5.526)\end{array}$ & $\begin{array}{c}0.846^{* * *} \\
(8.671)\end{array}$ \\
\hline \multirow[t]{2}{*}{ Rival } & 9.380 & 21.804 & -6.589 & 4.539 \\
\hline & $(0.227)$ & $(0.613)$ & $(-0.702)$ & $(0.449)$ \\
\hline \multirow[t]{2}{*}{ Listing Premium $\times$ Rival } & $-0.627^{* *}$ & 0.085 & $-0.425^{* *}$ & 0.102 \\
\hline & $(-2.074)$ & $(0.614)$ & $(-2.310)$ & $(0.643)$ \\
\hline \multirow[t]{2}{*}{ Opponent's Rank } & -15.133 & $-94.207^{*}$ & $-23.538^{*}$ & 1.504 \\
\hline & $(-0.893)$ & $(-2.277)$ & $(-1.995)$ & $(0.092)$ \\
\hline \multirow[t]{2}{*}{ Home Team's Rank } & $-49.550^{* *}$ & -24.780 & $-17.303^{*}$ & -16.149 \\
\hline & $(-3.049)$ & $(-0.894)$ & $(-1.921)$ & $(-1.685)$ \\
\hline \multirow[t]{2}{*}{ Prime Time } & -11.533 & 56.585 & 6.543 & 10.981 \\
\hline & $(-0.454)$ & $(1.601)$ & $(0.584)$ & $(0.997)$ \\
\hline \multirow[t]{2}{*}{ Pre-Season Top Opponent } & 75.666 & 15.940 & -0.141 & 9.714 \\
\hline & $(1.817)$ & $(0.352)$ & $(-0.018)$ & (1.309) \\
\hline \multirow{2}{*}{ Homecoming } & -6.448 & 37.520 & 3.382 & 9.004 \\
\hline & $(-0.419)$ & $(1.179)$ & $(0.319)$ & $(0.729)$ \\
\hline \multirow[t]{2}{*}{ Distance } & -3.959 & 4.120 & -6.287 & -2.697 \\
\hline & $(-0.219)$ & $(0.190)$ & $(-1.054)$ & $(-0.396)$ \\
\hline \multirow[t]{2}{*}{ Number of Units } & 90.181 & 137.471 & -11.706 & -52.401 \\
\hline & $(1.202)$ & $(1.341)$ & $(-0.209)$ & $(-0.764)$ \\
\hline \multirow[t]{2}{*}{ Hotel Premium } & -0.884 & -0.702 & $1.484^{* * *}$ & $1.338^{* *}$ \\
\hline & $(-0.973)$ & $(-1.074)$ & $(4.192)$ & $(2.815)$ \\
\hline \multirow[t]{2}{*}{ Same Conference } & $105.868^{* *}$ & $94.134^{* *}$ & 23.644 & 12.146 \\
\hline & $(2.981)$ & $(3.192)$ & $(1.080)$ & $(1.247)$ \\
\hline \multirow[t]{2}{*}{ Hotel Occupancy } & $7.625^{* * *}$ & 2.290 & $-1.186^{* *}$ & -0.665 \\
\hline & $(3.287)$ & $(1.101)$ & $(-2.190)$ & $(-0.955)$ \\
\hline Observations & 220 & 184 & 2,172 & 2,012 \\
\hline R-squared & 0.388 & 0.512 & 0.273 & 0.373 \\
\hline Number of Unique Units & 35 & 29 & 475 & 449 \\
\hline
\end{tabular}

This article is protected by copyright. All rights reserved. 


\section{Table 12: Listing Premium for Shared Units}

This table reports the coefficients from the unit fixed effects panel regression for shared units listed on Airbnb whose listing price changed at least once during the football season. For shared units, Airbnb Listing Premium is computed at the unit level as the listing price on a specific game minus the average listing price for all home games during the season. A low credit utilization score corresponds with financially unconstrained hosts, while a high credit utilization score corresponds with financially constrained hosts. Rival is an indicator variable that equals one if the home game is against a rival opponent, and zero otherwise. Homecoming is an indicator variable equal to one if the game takes place on the homecoming weekend, and zero otherwise. Opponent's Rank is the incoming rank of the opponent prior to the start of the game, and equals 50 if the team is unranked. Home Team's Rank is the rank of the home team prior to the start of the game, and equals 50 if the team is unranked. Pre-Season Top 25 Opponent is an indicator variable equal to one if the incoming opponent was ranked a top 25 team on the Associated Press Poll at the start of the season, and zero otherwise. Prime Time Game is an indicator variable equal to one if the game occurs at $5 \mathrm{pm}$ or later, and zero otherwise. Distance refers to the number of miles separating the location of the home team and the visiting team. Same Conference is an indicator variable equal to one if the incoming opponent is in the same athletic conference as the home team. Hotel Premium is computed at the city level as the average hotel price on a specific game minus the average hotel price for all home games during the season, while Hotel Occupancy refers to the average hotel occupancy on a specific game. Appendix A contains the list of rival teams and Appendix B contains a description of each variable. $t$-statistics are reported in parentheses. Standard errors are clustered at the team level. ${ }^{*}, * *$, and $* * *$ indicate significance at the $10 \%, 5 \%$, and $1 \%$ levels, respectively.

\begin{tabular}{lccc}
\hline & Financially Unconstrained & & Financially Constrained \\
\cline { 2 - 3 } Rival & -0.817 & \\
& $(-0.142)$ & $(.376$ \\
Opponent's Rank & 0.980 & $1.628)$ \\
& $(0.341)$ & $(0.461)$ \\
Home Team's Rank & -1.106 & 0.883 \\
& $(-0.410)$ & $(0.354)$ \\
Prime Time Game & -2.656 & -0.636 \\
& $(-0.981)$ & $(-0.402)$ \\
Pre-Season Top Opponent & 3.609 & 1.433 \\
& $(1.217)$ & $(0.474)$ \\
Homecoming & 1.656 & 0.572 \\
& $(1.075)$ & $(0.331)$ \\
Distance & -0.840 & -0.024 \\
& $(-1.253)$ & $(-0.015)$ \\
Same Conference & -3.852 & -2.715 \\
& $(-1.158)$ & $(-0.744)$ \\
Hotel Premium & $0.326^{* * *}$ & 0.196 \\
& $(3.216)$ & $(0.909)$ \\
Hotel Occupancy & $-0.274^{*}$ & -0.082 \\
& $(-2.010)$ & $(-0.360)$ \\
Number of Shared Units & -1.361 & 0.294 \\
& $(-0.504)$ & $(0.107)$ \\
Observations & 972 & 958 \\
R-squared & 0.072 & 0.045 \\
Number of Unique Units & 202 & 200 \\
\hline
\end{tabular}

This article is protected by copyright. All rights reserved. 


\section{Table 13: Stadium Incidents}

This table reports the coefficients from a team fixed effects regression explaining the number of stadium incidents, defined as the sum of disorderly conduct violations at the stadium and stadium ejections on each home game. Rival is an indicator variable that equals one if the home game is against a rival opponent, and zero otherwise. Homecoming is an indicator variable equal to one if the game takes place on the homecoming weekend, and zero otherwise. Prime Time Game is an indicator variable equal to one if the game occurs at $5 \mathrm{pm}$ or later, and zero otherwise. Opponent's Rank is the incoming rank of the opponent prior to the start of the game, and equals 50 if the team is unranked. Home Team's Rank is the rank of the home team prior to the start of the game, and equals 50 if the team is unranked. Pre-Season Top 25 Opponent is an indicator variable equal to one if the incoming opponent was ranked a top 25 team on the Associated Press Poll at the start of the season, and zero otherwise. Same Conference is an indicator variable equal to one if the incoming opponent is in the same athletic conference as the home team. Distance refers to the number of miles separating the location of the home team and the visiting team. Appendix A contains the list of rival teams and Appendix B contains a description of each variable. $t$-statistics are reported in parentheses. Standard errors are clustered at the team level. ${ }^{*},{ }^{*}$, and $* * *$ indicate significance at the $10 \%, 5 \%$, and $1 \%$ levels, respectively.

\begin{tabular}{|c|c|c|c|c|c|c|c|}
\hline \multirow[b]{2}{*}{ Rival } & \multicolumn{7}{|c|}{ Stadium Incidents } \\
\hline & $\begin{array}{c}25.292^{* * *} \\
(3.491)\end{array}$ & $\begin{array}{c}24.009 * * * \\
(3.422)\end{array}$ & $\begin{array}{c}24.401^{* * *} \\
(3.486)\end{array}$ & $\begin{array}{c}18.974^{* * *} \\
(2.966)\end{array}$ & $\begin{array}{c}17.801^{* *} \\
(2.789)\end{array}$ & $\begin{array}{c}16.064^{* *} \\
(2.675)\end{array}$ & $\begin{array}{c}15.607^{* *} \\
(2.390)\end{array}$ \\
\hline Homecoming & & $\begin{array}{c}-8.893^{* *} \\
(-2.308)\end{array}$ & $\begin{array}{c}-7.943^{* *} \\
(-2.128)\end{array}$ & $\begin{array}{c}-7.443^{* *} \\
(-2.263)\end{array}$ & $\begin{array}{c}-6.634^{* *} \\
(-2.442)\end{array}$ & $\begin{array}{c}-5.998^{* *} \\
(-2.244)\end{array}$ & $\begin{array}{c}-6.478 \\
(-1.699)\end{array}$ \\
\hline Prime Time Game & & & $\begin{array}{c}21.746^{* *} \\
(2.872)\end{array}$ & $\begin{array}{c}19.427^{* *} \\
(2.772)\end{array}$ & $\begin{array}{c}18.886^{* *} \\
(2.877)\end{array}$ & $\begin{array}{c}16.145^{* *} \\
(2.749)\end{array}$ & $\begin{array}{c}16.281^{* *} \\
(2.779)\end{array}$ \\
\hline Opponent's Rank & & & & $\begin{array}{c}-14.312^{* *} \\
(-2.543)\end{array}$ & $\begin{array}{c}-13.876^{* *} \\
(-2.583)\end{array}$ & $\begin{array}{c}-8.846^{* *} \\
(-2.155)\end{array}$ & $\begin{array}{c}-8.864^{* *} \\
(-2.150)\end{array}$ \\
\hline Home Team's Rank & & & & & $\begin{array}{c}-6.764 \\
(-1.371)\end{array}$ & $\begin{array}{c}-6.862 \\
(-1.455)\end{array}$ & $\begin{array}{c}-6.902 \\
(-1.489)\end{array}$ \\
\hline Pre-Season Top Opponent & & & & & & $\begin{array}{c}15.638^{* *} \\
(2.655)\end{array}$ & $\begin{array}{c}14.967^{* *} \\
(2.383)\end{array}$ \\
\hline Same Conference & & & & & & & $\begin{array}{c}1.529 \\
(0.212)\end{array}$ \\
\hline Team Fixed Effects & Yes & Yes & Yes & Yes & Yes & Yes & Yes \\
\hline Observations & 214 & 214 & 214 & 214 & 214 & 214 & 214 \\
\hline R-squared & 0.506 & 0.512 & 0.563 & 0.613 & 0.621 & 0.637 & 0.637 \\
\hline
\end{tabular}

This article is protected by copyright. All rights reserved. 


\section{Appendix A: List of Home Games Against Rivals}

\begin{tabular}{|c|c|c|c|c|c|}
\hline Home Team & Opponent & Year & Home Team & Opponent & Year \\
\hline South Carolina & Georgia & 2014 & South Carolina & Clemson & 2015 \\
\hline Georgia & Georgia Tech & 2014 & Clemson & Georgia Tech & 2015 \\
\hline Florida State & Florida & 2014 & Georgia & South Carolina & 2015 \\
\hline Florida & LSU & 2014 & Florida State & Miami & 2015 \\
\hline Tennessee & Kentucky & 2014 & Florida & Florida State & 2015 \\
\hline Kentucky & Vanderbilt & 2014 & Alabama & LSU & 2015 \\
\hline Ohio State & Michigan & 2014 & Auburn & Alabama & 2015 \\
\hline Iowa & Iowa State & 2014 & Tennessee & Vanderbilt & 2015 \\
\hline Iowa & Wisconsin & 2014 & Mississippi State & LSU & 2015 \\
\hline Wisconsin & Minnesota & 2014 & Mississippi State & Alabama & 2015 \\
\hline Nebraska & Minnesota & 2014 & Kentucky & Tennessee & 2015 \\
\hline LSU & Mississippi State & 2014 & Notre Dame & USC & 2015 \\
\hline LSU & Alabama & 2014 & Michigan & Michigan State & 2015 \\
\hline Arkansas & LSU & 2014 & Michigan & Ohio State & 2015 \\
\hline Arkansas & Ole Miss & 2014 & Michigan St. & Indiana & 2015 \\
\hline Oklahoma & Oklahoma State & 2014 & Iowa & Minnesota & 2015 \\
\hline TCU & Texas Tech & 2014 & Wisconsin & Iowa & 2015 \\
\hline Texas Tech & Texas & 2014 & LSU & Florida & 2015 \\
\hline Oregon State & Oregon & 2014 & LSU & Arkansas & 2015 \\
\hline \multirow[t]{3}{*}{ Oregon } & Washington & 2014 & Texas Tech & TCU & 2015 \\
\hline & & & Utah & Colorado & 2015 \\
\hline & & & $\mathrm{ASU}$ & Arizona & 2015 \\
\hline
\end{tabular}

This article is protected by copyright. All rights reserved. 


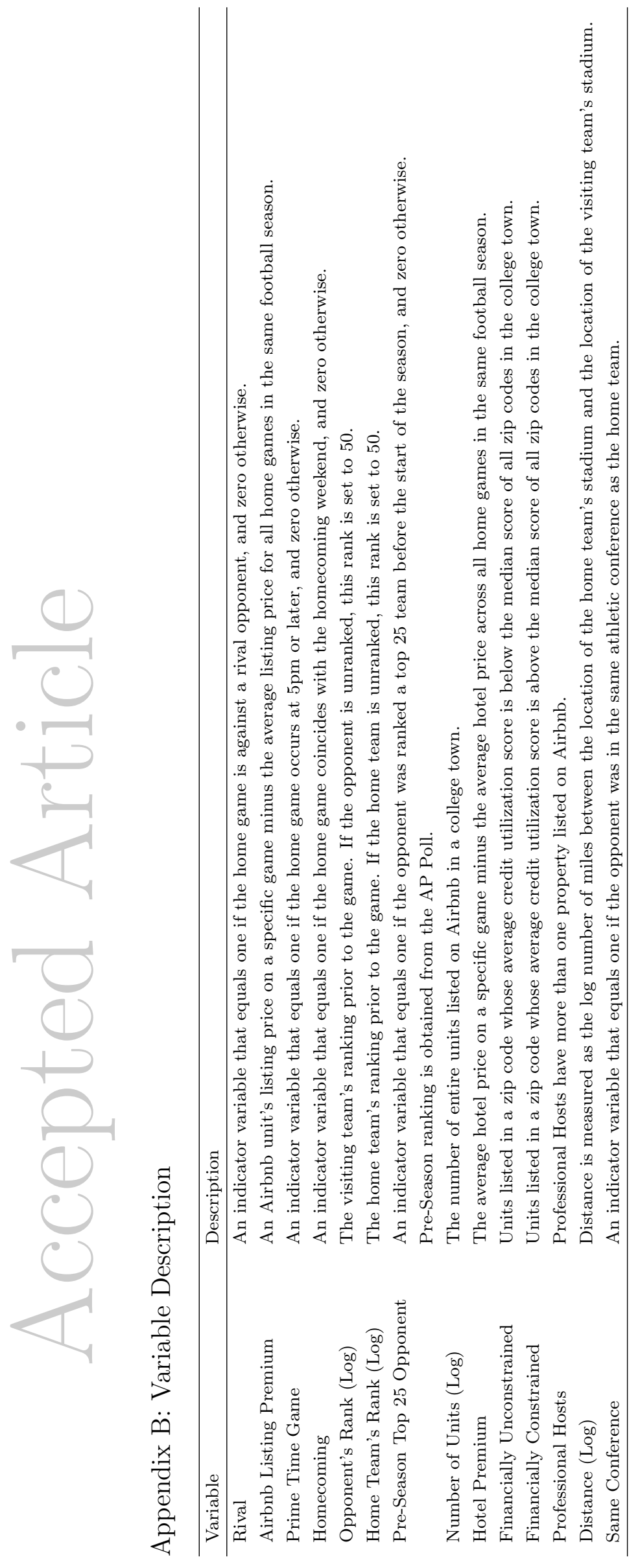

This article is protected by copyright. All rights reserved. 